\title{
In situ, satellite measurement and model evidence on the dominant regional contribution to fine particulate matter levels in the Paris megacity
}

M. Beekmann ${ }^{1}$ A. S. H. Prévôt ${ }^{2}$, F. Drewnick ${ }^{3}$ J. Sciare ${ }^{4, a}$, S. N. Pandis ${ }^{5}$ H. A. C. Denier van der Gon $^{6}$, M. Crippa $^{2}$

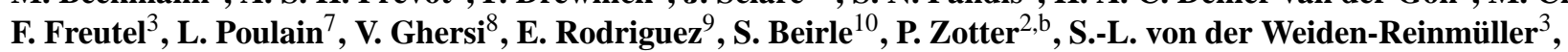
M. Bressi ${ }^{4}$, C. Fountoukis ${ }^{5}$, H. Petetin ${ }^{1,8}$, S. Szidat ${ }^{11}$, J. Schneider ${ }^{3}$, A. Rosso ${ }^{8}$, I. El Haddad ${ }^{2}$, A. Megaritis ${ }^{5}$, Q. J. Zhang ${ }^{1,12}$, V. Michoud ${ }^{1,20}$, J. G. Slowik ${ }^{2}$, S. Moukhtar ${ }^{8}$, P. Kolmonen ${ }^{9}$, A. Stohl ${ }^{13}$, S. Eckhardt ${ }^{13}$, A. Borbon ${ }^{1}$, V. Gros ${ }^{4}$, N. Marchand ${ }^{14}$, J. L. Jaffrezo ${ }^{15}$, A. Schwarzenboeck ${ }^{16}$, A. Colomb ${ }^{1,16}$, A. Wiedensohler ${ }^{7}$, S. Borrmann ${ }^{3,17}$, M. Lawrence ${ }^{18, \mathrm{c}}$, A. Baklanov ${ }^{19}$, and U. Baltensperger ${ }^{2}$

${ }^{1}$ LISA/IPSL, Laboratoire Interuniversitaire des Systèmes Atmosphériques, UMR CNRS 7583, Université Paris Est Créteil (UPEC) et Université Paris Diderot (UPD), Créteil, France

${ }^{2}$ Laboratory of Atmospheric Chemistry, Paul Scherrer Institute, PSI, Villigen, Switzerland

${ }^{3}$ Particle Chemistry Department, Max Planck Institute for Chemistry, Mainz, Germany

${ }^{4}$ Laboratoire des Sciences du Climat et de l'Environnement (LSCE/IPSL), Laboratoire CEA-CNRS-UVSQ, Gif-sur-Yvette, France

${ }^{5}$ Institute of Chemical Engineering Sciences (ICEHT), Foundation for Research and Technology Hellas (FORTH), Patra,

Greece

${ }^{6}$ Department of Climate, Air and Sustainability, TNO, Utrecht, the Netherlands

${ }^{7}$ Leibniz Institute for Tropospheric Research, Leipzig, Germany

${ }^{8}$ AIRPARIF, Agence de Surveillance de la Qualité de l'Air, Paris, France

${ }^{9}$ Climate Change Unit, Finnish Meteorological Institute, 00101, Finland

${ }^{10}$ Max Planck Institute for Chemistry, Satellite Group, Mainz, Germany

${ }^{11}$ Department of Chemistry and Biochemistry \& Oeschger Centre for Climate Change Research, University of Bern, Bern, Switzerland

${ }^{12}$ Aria Technologies, Boulogne Billancourt, France

${ }^{13}$ NILU - Norwegian Institute for Air Research, Kjeller, Norway

${ }^{14}$ Laboratoire Chimie Provence, Equipe Instrumentation et Réactivité Atmosphérique (IRA), Université

d'Aix-Marseille-CNRS, Marseille, France

${ }^{15}$ Laboratoire de Glaciologie et Géophysique de l'Environnement (LGGE), Université Joseph Fourier, CNRS, Grenoble,

France

${ }^{16}$ Laboratoire de Météorologie Physique (LaMP), Université Blaise Pascal, CNRS, Aubière, France

${ }^{17}$ Institute of Atmospheric Physics, Johannes Gutenberg University Mainz, Mainz, Germany

${ }^{18}$ Department of Atmospheric Chemistry, Max Planck Institute for Chemistry, Mainz, Germany

${ }^{19}$ Danish Meteorological Institute (DMI), Research Department, Copenhagen, Denmark

${ }^{20}$ Mines de Douai, Douai, France

${ }^{a}$ now at: Energy Environment Water Research Center (EEWRC), The Cyprus Institute, Nicosia, Cyprus

${ }^{b}$ now at: Lucerne School of Engineering and Architecture, Bioenergy Research, Lucerne University of Applied Sciences and Arts, 6048 Horw, Switzerland

${ }^{c}$ now at: Institute for Advanced Sustainability Studies, Potsdam, Germany

Correspondence to: M. Beekmann (matthias.beekmann@lisa.u-pec.fr)

Received: 21 January 2015 - Published in Atmos. Chem. Phys. Discuss.: 23 March 2015

Revised: 25 July 2015 - Accepted: 4 August 2015 - Published: 27 August 2015

Published by Copernicus Publications on behalf of the European Geosciences Union. 


\begin{abstract}
A detailed characterization of air quality in the megacity of Paris (France) during two 1-month intensive campaigns and from additional 1-year observations revealed that about $70 \%$ of the urban background fine particulate matter (PM) is transported on average into the megacity from upwind regions. This dominant influence of regional sources was confirmed by in situ measurements during short intensive and longer-term campaigns, aerosol optical depth (AOD) measurements from ENVISAT, and modeling results from PMCAMx and CHIMERE chemistry transport models. While advection of sulfate is well documented for other megacities, there was surprisingly high contribution from long-range transport for both nitrate and organic aerosol. The origin of organic PM was investigated by comprehensive analysis of aerosol mass spectrometer (AMS), radiocarbon and tracer measurements during two intensive campaigns. Primary fossil fuel combustion emissions constituted less than $20 \%$ in winter and $40 \%$ in summer of carbonaceous fine PM, unexpectedly small for a megacity. Cooking activities and, during winter, residential wood burning are the major primary organic PM sources. This analysis suggests that the major part of secondary organic aerosol is of modern origin, i.e., from biogenic precursors and from wood burning. Black carbon concentrations are on the lower end of values encountered in megacities worldwide, but still represent an issue for air quality. These comparatively low air pollution levels are due to a combination of low emissions per inhabitant, flat terrain, and a meteorology that is in general not conducive to local pollution build-up. This revised picture of a megacity only being partially responsible for its own average and peak PM levels has important implications for air pollution regulation policies.
\end{abstract}

\section{Introduction}

Megacities, defined as agglomerations with a population above 10 million inhabitants (Gurjar and Lelieveld, 2005) often concentrate in a small area a substantial part of a country's population, economic activities, and thus air pollutant emissions. Emitted primary and subsequently formed secondary gas- or particulate-phase pollutants cause substantial health problems especially in megacities with rapidly growing industry and low pollution control (e.g., Gurjar et al., 2010). The impact of local emissions on air quality in many of these megacities was shown to be large (see, e.g., Molina and Molina, 2004, for a general overview; Hand et al., 2011, and Parrish et al., 2011, for Los Angeles; Molina et al., 2010, for Mexico City; Chan and Yao, 2008, for Chinese megacities). In addition to the local contribution, levels of gaseous species and of fine particulate matter (fine $\mathrm{PM}$, with an aerodynamic diameter below $2.5 \mu \mathrm{m}, \mathrm{PM}_{2.5}$ ) are also affected by long-range transport from outside the cities. This important role of pollutant transport has been first shown for sulfate in New York City, a megacity located in a highly industrialized belt in the northeastern US (Rahn and Lowenthal, 1985; Dutkiewicz et al., 2004; Quin et al., 2006). Indeed, as a secondary aerosol component, sulfate needs some time to be formed from $\mathrm{SO}_{2}$ emissions by gaseousor aqueous-phase oxidation pathways (Seinfeld and Pandis, 2006), important $\mathrm{SO}_{2}$ emissions of industrial origin are often located outside of a megacity. For nitrate, another important secondary inorganic aerosol component, and for organic aerosol (OA; both of primary and secondary origin), only few explicit estimations of the local versus advected contributions to their burden in megacities are available. While for Chicago (with about 8.75 million inhabitants is nearly a megacity) the advected part for both nitrate and OA is dominant (about $60 \%$ (Hand et al., 2011)), it is only minor for New York City (about 30-40\%) (Lall and Thurston, 2006; Hand et al., 2011). Important contributions to nitrate from advection were qualitatively estimated for London (Harrison et al., 2012).

Inorganic secondary particulate species are directly related to their precursor gases $\mathrm{SO}_{2}, \mathrm{NO}_{x}$ and $\mathrm{NH}_{3}$, with rather well known sources mostly related to fossil fuel burning $\left(\mathrm{SO}_{2}\right.$, $\mathrm{NO}_{x}$ ) and agriculture $\left(\mathrm{NH}_{3}\right)$. By contrast, sources of organic aerosol are widespread (road transport, residential heating including wood burning, open biomass burning, cooking activities, secondary formation from biogenic as well as anthropogenic volatile organic compound (VOC) precursors) and their relative contributions remain uncertain (Hallquist et al., 2009). Early source apportionment work on PM was based on the analysis of daily filter samples and analysis of correlations between organic aerosol and tracers for specific sources using different statistical methods (for a review of methods and results, see Viana et al., 2008). In these earlier studies the secondary OA was often determined as the part of OA which could not be attributed to primary sources.

More recently, the combination of aerosol mass spectrometer (AMS) measurements (DeCarlo et al., 2006; Drewnick et al., 2005) and factor analysis techniques (e.g., positive matrix factorization, PMF, Paatero and Tapper, 1994; Lanz et al., 2007; Ulbrich et al., 2009) has improved the high temporal resolution of source apportionment of primary and secondary OA (e.g., Jimenez et al., 2009; Zhang et al., 2011). Nevertheless, the biogenic versus anthropogenic origin of secondary aerosol in megacities and in megacity plumes is still an open question (Hallquist et al., 2009). The combination of radiocarbon $\left({ }^{14} \mathrm{C}\right)$ measurements and AMS based source apportionment can provide valuable insights about the share of fossil fuel and contemporary organic aerosol sources (Lanz et al., 2007; Minguillón et al., 2011; El-Haddad et al., 2013; Zotter et al., 2014). Despite this progress, sources of organic aerosol in megacities with respect to their local versus advected and fossil fuel versus contemporary contribution are 
still highly uncertain. Comprehensive data sets are needed to better quantify these sources.

Here, we report measurements of air pollution of fine particles in the Paris agglomeration, a mid-latitude, postindustrial megacity with 10.84 million inhabitants (United Nations, 2015). We conducted two intensive field campaigns in the Greater Paris area during July 2009 and from midJanuary to mid-February 2010 as part of the MEGAPOLI (Megacities: Emissions, urban, regional and Global Atmospheric POLlution and climate effects, and Integrated tools for assessment and mitigation) project (Butler, 2008; Baklanov et al., 2010). In addition, for 1 year (September 2009September 2010), daily $\mathrm{PM}_{2.5}$ chemical composition measurements were performed at one urban background and several rural sites during the PARTICULES (Source Apportionment Of Airborne Particles In The Ile-de-France Region) project (Ghersi et al., 2010; Bressi et al., 2013, 2014). Our major aim is to quantify the contribution of local versus advected sources of fine aerosol in a post-industrial megacity, with a special focus on organic aerosol sources. This will be addressed by combining observations from both the MEGAPOLI and PARTICULES campaigns, and also considering results from chemical transport modeling and satellite observations. The analysis of organic aerosol sources will be addressed by a synthesis of AMS, radiocarbon and tracer measurements. Finally, we will place results found for Paris in a larger context of particulate matter origin in other selected megacities.

\section{Measurements and methods}

In Sect. 2.1, we will present the sites and measurements used for this study during the MEGAPOLI and PARTICULES campaigns. The processing of the measurements will be described in Sect. 2.2. The analysis for attribution of local versus advected contributions is outlined in Sect. 2.3. Details of the combined use of ${ }^{14} \mathrm{C}$ and AMS data are given in the Supplement in Sect. S1. Additional data sets used in this study are described in the Supplement: satellite data sets (aerosol optical depth (AOD) from the Advanced Along Track Scanning Radiometer (AATSR), $\mathrm{NO}_{2}$ columns from the SCIAMACHY instrument, both on the ENVISAT platform) in Sect. S2, black carbon (BC) and elemental carbon (EC) observations from other megacities than Paris in Sect. S3, emission inventories in Sect. S4 and modeling simulations with the PMCAMx and the CHIMERE models in Sect. S5.

\subsection{Sampling sites and strategy}

MEGAPOLI summer and winter campaigns took place from 1 to 31 July 2009 and 15 January to 15 February 2010. The measurement design included three primary and several secondary sites (Crippa et al., 2013b; Freutel et al., 2013), mobile platforms (Royer et al., 2011; von der Weiden-

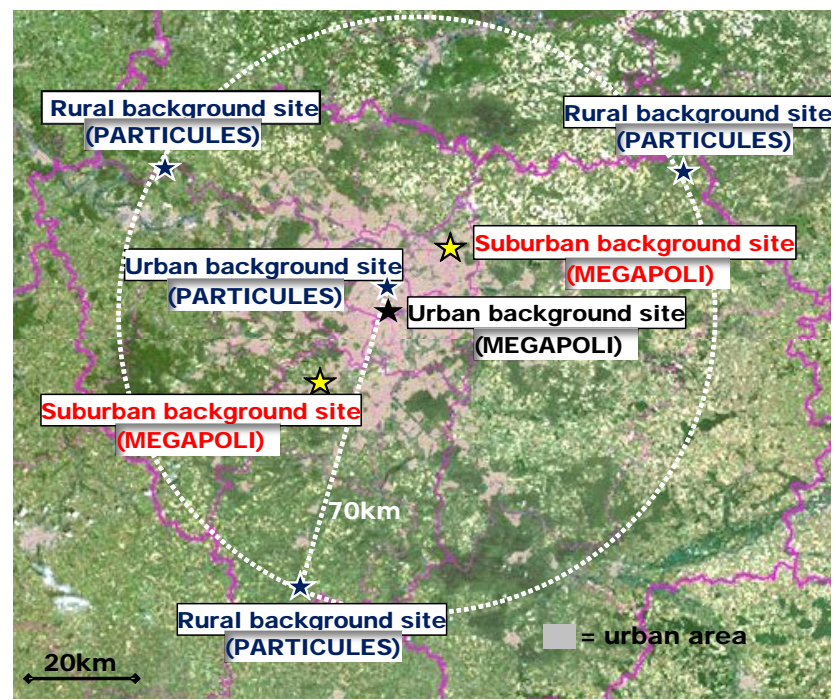

Figure 1. Location of the sampling sites from the MEGAPOLI and PARTICULES projects in the Ile-de-France region. The zone in beige color stands for the urban area of the Paris agglomeration. The white circle shows the three rural background sites, all at about $70 \mathrm{~km}$ distance from the PARTICULES urban background site. The purple lines indicate administrative boundaries. Map source: Google Earth.

Reinmüller et al., 2014a), and an aircraft (Freney et al., 2014). Measurements at primary sites include gas-phase pollutants, size-resolved chemical composition of fine PM, and aerosol physical properties. In this paper, we use in particular concurrent AMS and black carbon measurements derived either from a MAAP (Multi Angle Absorption Photometer; Thermo) or an Aethalometer (Magee Scientific, model AE31, USA) at the three primary sites. The urban background site (LHVP, Laboratoire d'Hygiène de la Ville de Paris) was located near the agglomeration center, in the 13th district of Paris. Two suburban background sites were located respectively at the southwestern (SW) and northeastern (NE) edges of the agglomeration, about $20 \mathrm{~km}$ from the city center (Fig. 1): the SIRTA (Site Instrumental de Recherche par Télédétection Atmosphérique, Haeffelin et al., 2005) site at Ecole Polytechnique, Palaiseau (later on referred to as SW suburban site) and the Golf Départemental de la Poudrerie site at Livry Gargan (NE suburban site). The sites are described in more details in Freutel et al. (2013) and Crippa et al. (2013b). At the urban site, filter sampling for ${ }^{14} \mathrm{C}$ analysis of $\mathrm{PM}_{1}$ aerosol was also performed in order to distinguish between fossil and modern fuel origin (see Sect. S1 for a detailed method description). Briefly, in these samples TC (total carbon) was isolated for ${ }^{14} \mathrm{C}$ measurements using the THEODORE (Two-step Heating system for the EC/OC Determination Of Radiocarbon $\left({ }^{14} \mathrm{C}\right)$ in the Environment) system (combustion in $\mathrm{O}_{2}$ at $640^{\circ} \mathrm{C}$ for $12 \mathrm{~min}$ and subsequent cryo-trapping of the evolving $\mathrm{CO}_{2}$, see Szidat et al. (2004) for more details). ${ }^{14} \mathrm{C}$ was then measured 
with the accelerator mass spectrometry system MICADAS (MIni CArbon DAting System) (Synal et al., 2007). The French PARTICULES project (Ghersi et al., 2010; Bressi et al., 2013) was designed to identify the major sources of $\mathrm{PM}_{2.5}$ in the city of Paris and document their geographical origin in order to better define effective local abatement strategies. A 1-year survey of the daily $\mathrm{PM}_{2.5}$ chemical composition (from 11 September 2009 to 10 September 2010) was performed at five background locations in the region of Paris (Fig. 1): one urban background, one suburban background (not used in this study), and three rural background sites at about $70 \mathrm{~km}$ distance from the city center. Additional measurements (not used in this study) were performed at two traffic sites. Each site was equipped with two automated lowvolume samplers (Leckel SEQ47/50) collecting $24 \mathrm{~h} \mathrm{PM} 2.5$ samples (from midnight to midnight) in order to determine the concentrations of $\mathrm{PM}_{2.5}$, elemental carbon (EC), organic carbon (OC), the major water-soluble inorganic ions, metals, and selected organic tracers such as levoglucosan (a marker for wood burning) as described in Bressi et al. (2013). From filter samples, total $\mathrm{PM}_{2.5}$ mass was obtained from gravimetric measurements. Chloride, nitrate, sulfate, sodium, ammonium, potassium, magnesium and calcium concentrations were determined by Ion Chromatography (IC). EC and OC were determined by a thermal-optical method using a Sunset Laboratory Carbon Analyzer (Sunset Lab., OR, USA) and the EUSAAR 2 protocol defined by Cavalli et al. (2010).

\subsection{Aerosol measurements processing}

AMS measurements provide the chemical speciation (sulfate, nitrate, ammonium, chloride, and the organic fraction) of the non-refractory fraction of aerosols with a diameter below $1 \mu \mathrm{m}\left(\mathrm{PM}_{1}\right)$. The uncertainty in these measurements has been estimated at about $30 \%$ (Crippa et al., 2013b; Freutel et al., 2013). Positive matrix factorization (PMF) (Paatero and Tapper, 1994; Lanz et al., 2007; Ulbrich et al., 2009) allows deconvolution of the OA mass spectra into several factors that can be assigned most of the time to specific OA sources. Error analysis for PMF output is performed by varying the algorithm parameters (seeds, fpeak). A relative uncertainty for different factors of usually several tens of percent has been obtained (Freutel et al., 2013). The PMF analysis was applied here to the AMS measurements at the three primary MEGAPOLI sites indicated in Fig. 1. For the summer campaign a three-factor solution comprising HOA (hydrocarbonlike organic aerosol), OOA (oxygenated organic aerosol) and COA (cooking-related organic aerosol) was selected (Freutel et al., 2013). For the winter campaign a four-factor solution with an additional BBOA (biomass-burning-related organic aerosol) component was selected (Crippa et al., 2013b).

The combination of radiocarbon $\left({ }^{14} \mathrm{C}\right)$ analysis with PMF analysis of AMS measurements allows quantification of the fossil fuel and modern fractions of different OA sources (Minguillón et al., 2011; El Haddad et al., 2013; Zotter et al., 2014). All PMF factors (as obtained with a three-factor analysis by Freutel et al., 2013) are attributed a priori to fossil fuel or modern (non-fossil fuel) carbon. HOA, which largely originates from road transport, was assumed to be $100 \%$ fossil fuel, thus neglecting the small biofuel contribution. COA and BBOA were assumed to be $100 \%$ non-fossil fuel. Only for OOA is this attribution not possible a priori, but it is obtained as a result of the combined ${ }^{14} \mathrm{C} / \mathrm{AMS}-\mathrm{PMF}$ analysis. For a more detailed description of this analysis, see Sect. 1 of the Supplement.

The measurement setup, data processing, and the data sets obtained from the PARTICULES project are described in detail in Bressi et al. (2013). Chemical mass closure was successfully achieved at all sites leading to a large quality controlled aerosol data set (Bressi et al., 2013).

\subsection{Data processing for determining local versus advected contributions}

The geographical origins of the various PM components measured during the PARTICULES campaign were determined assuming that the difference in PM chemical composition between the urban background site and the appropriate upwind rural site can be attributed to the emissions within the agglomeration (Lenschow et al., 2001). Backward trajectories calculated with the HYSPLIT model (Draxler and Hess, 1997) have been used to choose the convenient rural background site upwind of the agglomeration among the three sites located at the northeast, northwest and south of the agglomeration (as described in more details in Petetin et al., 2014). Uncertainties in the annual advected fractions are below $5 \%$ (Petetin et al., 2014).

\section{Aerosol origin: regional or local?}

\subsection{MEGAPOLI intensive campaign perspective}

A first striking result is that $\mathrm{PM}_{1}$ levels in the Paris agglomeration were much lower during the MEGAPOLI summer campaign in July 2009 than during the winter campaign (in January/February 2010): average $\mathrm{PM}_{1}$ levels were between 5.3 and $7.5 \mu \mathrm{g} \mathrm{m}^{-3}$ and between 15.2 and $18.5 \mu \mathrm{g} \mathrm{m}^{-3}$ in summer and winter, respectively, at the three primary sites (Table S1 in Supplement; Freutel et al., 2013, Crippa et al., 2013b). This seasonal variation of $\mathrm{PM}_{1}$ is confirmed at the SW suburban site by 2-year (June 2011-June 2013) combined QACSM (Quadripole Aerosol Chemical Speciation Monitor, Aerodyne, MA, USA) and Aethalometer measurements (Petit et al., 2015): summer $\mathrm{PM}_{1}$ were on average $4.4 \mu \mathrm{g} \mathrm{m}^{-3}$ while winter reached on average $14.5 \mu \mathrm{g} \mathrm{m}^{-3}$. Also, on a longer-term perspective, PM levels in the Paris megacity appear moderate, when compared to the European background: average urban background $\mathrm{PM}_{2.5}$ concentrations levels in and near Paris suburbs over the period 2007-2013 are about $18 \mathrm{\mu g} \mathrm{m}^{-3}$ (Petit, 2014). This value is similar to the median 

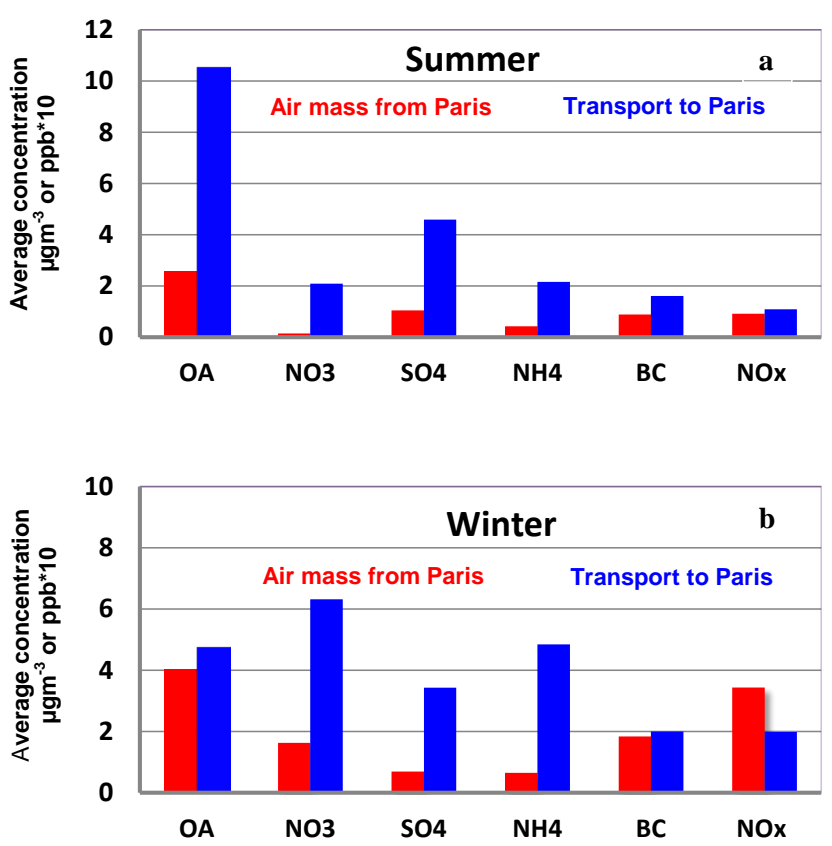

Figure 2. $\mathrm{PM}_{1}$ components $\left(\mu \mathrm{g} \mathrm{m}^{-3}\right)$ and $\mathrm{NO}_{x}(\mathrm{ppb} \times 10)$ at the NE suburban site for air masses arriving from SW (red bars) and NE sectors (blue bars); air masses originating from the SW sector sample emissions from Paris, those from the NE sector represent continental type air masses moving towards Paris: (a) for summer and (b) for winter.

value of the annual $\mathrm{PM}_{2.5}$ means of $17 \mu \mathrm{g} \mathrm{m}{ }^{-3}$ derived from eight European rural background sites (Putaud et al., 2010). Nevertheless, Paris urban $\mathrm{PM}_{2.5}$ background exceeds the WHO health guideline of $10 \mu \mathrm{g} \mathrm{m}^{-3}$ on an annual average; also European $\mathrm{PM}_{10}$ standards are exceeded for traffic sites. Average $\mathrm{PM}_{2.5}$ levels in Paris are rather close to European background levels, suggesting a strong regional contribution to the Paris background urban fine PM burden which needs to be confirmed by quantitative analysis presented here.

Firstly, time series were analyzed (Crippa et al., 2013b; Freutel et al., 2013). For all major aerosol components except black carbon, the average concentrations (Table S1 in the Supplement) and their temporal variability are rather similar between the urban LHVP and the NE and SW suburban sites, located at the edge of Paris. This similarity implies indeed a major regionally controlled fine PM burden.

Second, we compared levels of different $\mathrm{PM}_{1}$ components and $\mathrm{NO}_{x}$ at the $\mathrm{NE}$ suburban site for air masses originating from (see Sect. S6 in the Supplement): (1) the NE sector coming from central Europe and (2) the SW sector and after passing over the Paris agglomeration before reaching the measurement site. Inorganic ions (sulfate, nitrate and ammonium) and OA levels were substantially higher for air masses originating from the NE sector both during summer and winter (Fig. 2). This increase is less apparent for OA in winter because AMS measurements were not available during 26

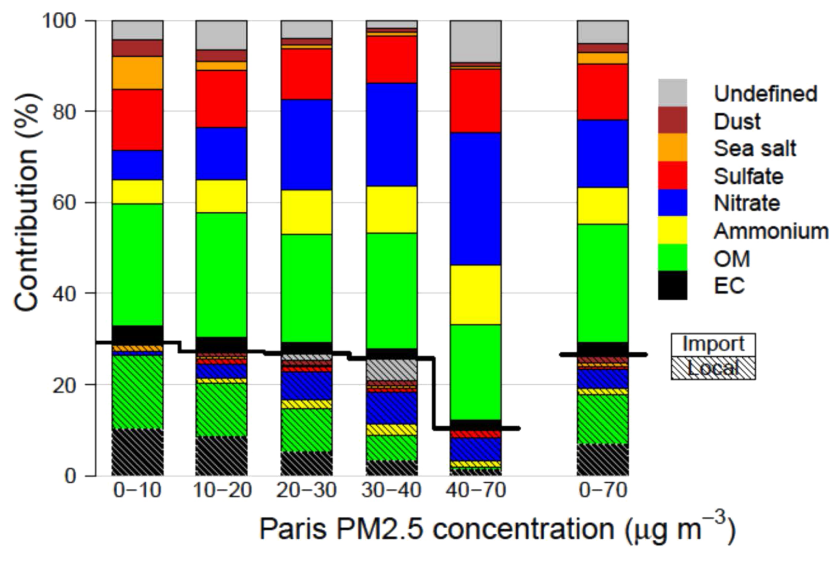

Figure 3. Local (hatched) and imported contributions to $\mathrm{PM}_{2.5}$ in Paris (PARTICULES urban background site) for the period September 2009 to September 2010, for different $\mathrm{PM}_{2.5}$ levels. An uncertainty range of $\pm 5 \%$ (absolute value) is estimated for the local and imported $\mathrm{PM}_{2.5}$ contribution.

to 28 January when heavily polluted air masses were transported to the agglomeration, and absent for $\mathrm{BC}$ and $\mathrm{NO}_{x}$, both primary pollutants. Thus contrary to intuitive expectations, PM levels for most components are larger in air masses advected to the agglomeration (from NE) than in air masses (from SW) leaving Paris and having accumulated urban emissions while crossing the city.

\subsection{One-year measurements perspective}

The dominance of regional pollution for fine PM levels was additionally quantified by the analysis of the year-long measurements from the PARTICULES project. Using the appropriate upwind rural site (see Sect. 2.2, Fig. 1) as background, we estimated that on an annual basis more than $70 \%$ of the urban $\mathrm{PM}_{2.5}$ was advected to Paris from outside (Fig. 3). Results from this analysis are very similar for the summer (JJA) and winter (DJF) seasons (72 and $71 \%$, respectively). During the polluted periods $\left(\mathrm{PM}_{2.5}>40 \mu \mathrm{g} \mathrm{m}^{-3}\right.$ at the urban site), especially during spring, the regional contribution can even be larger, around $90 \%$. Thus the variability of fine PM levels in Paris background atmosphere is mostly controlled by advection from outside.

The three major fine aerosol species sulfate, nitrate and organic aerosol at the urban background site on average constituted 13, 19 and $36 \%$, respectively, of total $\mathrm{PM}_{2.5}$. The predominance of advected aerosol compounds is observed as expected for sulfate (nearly $95 \%$ of total fine PM), but also for nitrate (nearly $80 \%$ ) and for organic matter (about $70 \%$ ). Such an important advected fraction of OA has to our knowledge not yet been shown before for a megacity. Possible reasons for this behavior will be discussed in Sect. 5 . 

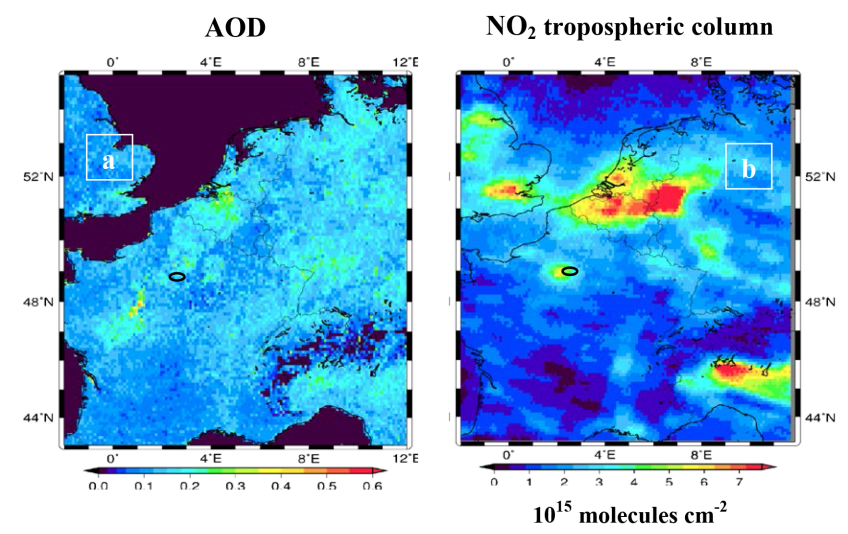

Figure 4. AOD (aerosol optical depth) from the AATSR (Advanced Along Track Scanning Radiometer instrument) (a), tropospheric $\mathrm{NO}_{2}$ columns from SCIAMACHY observations, both averaged over the period March-October 2009 (b). The black ovals marks the Paris agglomeration. AOD values are only given over land areas (black over sea).

\subsection{Satellite observations}

The homogeneous regional distribution of fine PM is also apparent from satellite AOD measurements, showing no significant gradient around Paris, in contrast to tropospheric $\mathrm{NO}_{2}$ column measurements (derived from SCIAMACHY measurements on ENVISAT), which are clearly enhanced over the Paris agglomeration (Fig. 4). This strong gradient in $\mathrm{NO}_{2}$ is directly related to $\mathrm{NO}_{x}$ emissions in the Paris agglomeration and is enhanced due to its short lifetime of several hours during daytime and summer (Beirle et al., 2011).

Figure 4 also shows the AOD results obtained with the Advanced Along Track Scanning Radiometer (AATSR) instrument on ENVISAT (Veefkind et al., 1998) over western Europe from March to October 2009. Around Paris (from 48.70 to $49.0^{\circ} \mathrm{N}$ and from 2.10 to $2.55^{\circ} \mathrm{E}$ ) AOD has a value of around $0.15 \pm 0.04$, while the average over northern France (from 49 to $50^{\circ} \mathrm{N}$ and from 2 to $6^{\circ} \mathrm{E}$ ) was $0.14 \pm 0.04$. Thus, unlike $\mathrm{NO}_{2}$, AOD is not affected by the Paris agglomeration. Therefore a megacity such as Paris does not significantly change the local AOD, which confirms results from surface observations of long-range transport dominance of the aerosol burden over the Paris area.

\subsection{Modeling results}

Results from chemical transport model (CTM) simulations (for model descriptions, see Sect. S5 in the Supplement) for the MEGAPOLI campaign and the year of PARTICULES measurements confirm the dominant advective contribution to PM levels over the Paris agglomeration. Simulations with the PMCAMx model show only 15 and $25 \%$ fine PM of local origin during the summer and winter campaign periods, respectively (Fig. 5). These values are about 10, 20 and 10\%

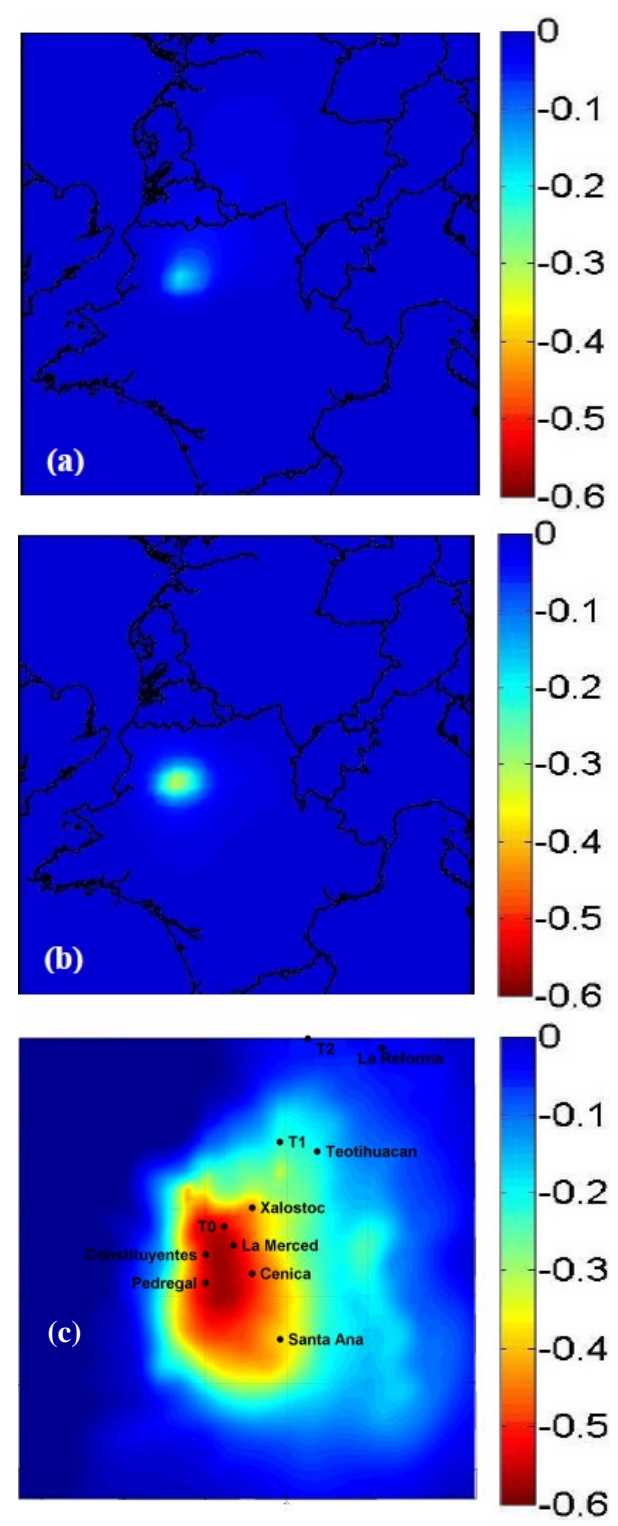

Figure 5. Predicted relative decrease in $\mathrm{PM}_{2.5}$ levels when local emissions of the megacity are set to zero; calculated with the PMCAMx model for the summer (a) and winter (b) MEGAPOLI campaigns for the greater Paris region, and during the MILAGRO (Megacity Initiative: Local And Global Research Observations) campaign (c) for Mexico City. Domain widths: $5400 \times 5832 \mathrm{~km}^{2}$ plus a subdomain of $216 \times 180 \mathrm{~km}^{2}$ for Paris, $210 \times 210 \mathrm{~km}^{2}$ for Mexico City.

for sulfate, nitrate and OA, respectively, during summer. For winter, the respective local contributions are more than 20,5 and $20 \%$ for the same compounds (Fig. 6). These values are obtained by comparing simulations with and without emissions from the Paris region. They are similar to those obtained by Skyllakou et al. (2014) for Paris using a specific tagging method imbedded in their PMCAMx model simulations, capable of discerning the geographical origin of fine 

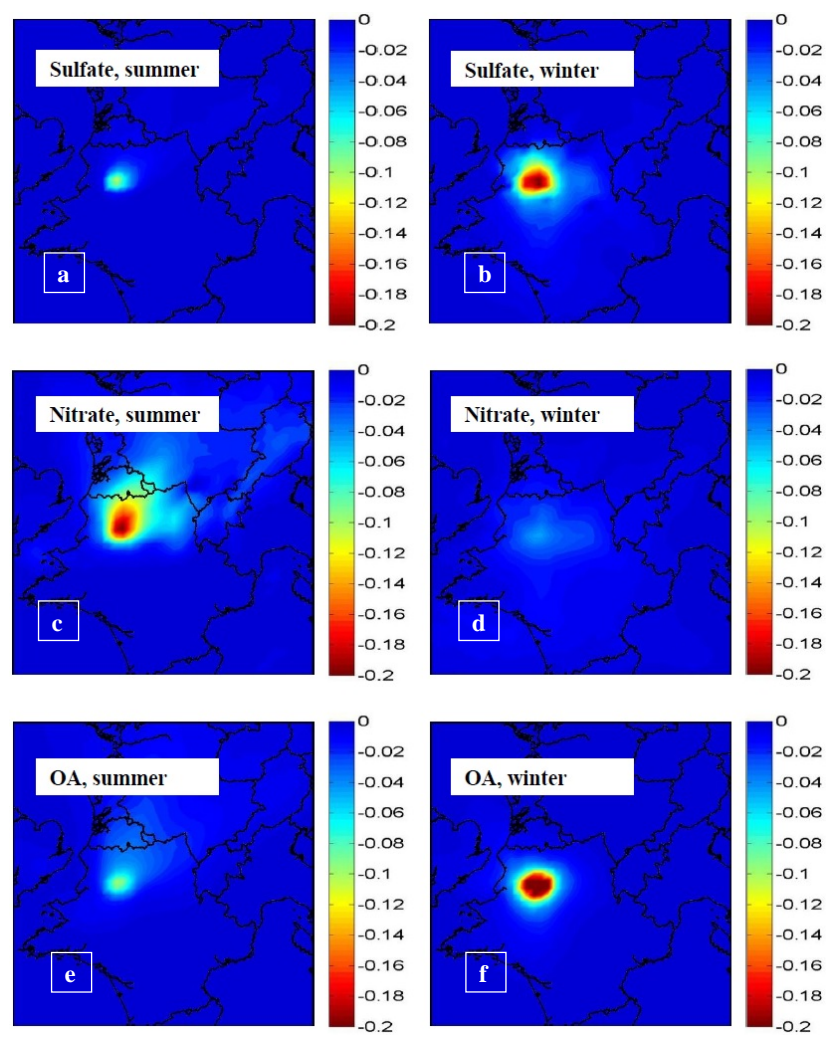

Figure 6. Simulated fractional decrease in $\mathrm{PM}_{2.5}$ sulfate $(\mathbf{a}, \mathbf{b})$, nitrate $(\mathbf{c}, \mathbf{d})$, and organic aerosol (OA; e, f) levels for the summer (a, $\mathbf{c}, \mathbf{d})$ and winter $(\mathbf{b}, \mathbf{d}, \mathbf{f})$ during the MEGAPOLI campaign period, when Paris agglomeration emissions are set to zero in the PMCAMx model.

PM. Also, simulations with the Polair3D/Polyphemus chemistry transport model (Sartelet et al., 2007) show a minor local contribution for OA (30-38\%) for the Paris urban background during the MEGAPOLI summer campaign (Couvidat et al., 2013).

Year-round simulations with the CHIMERE model also show, consistently with the observation-based estimates, that around $65 \%$ of the fine $\mathrm{PM}_{2.5}$ over Paris is advected to the megacity from other areas (Petetin et al., 2014). For individual compounds larger errors of different sign occur, for instance the advected part of OA is underestimated by CHIMERE by about a factor of 2 , while nitrate is overestimated by a factor of 1.5. The strong underestimation of OA is most pronounced during wintertime and is thought to be related both to underestimated regional wood-burning emissions and missing formation pathways in the model (Petetin et al., 2014). In conclusion CTM simulations are able to reproduce and confirm the general picture of a dominant advected fine PM burden over the Paris domain, although errors can occur for individual aerosol species.

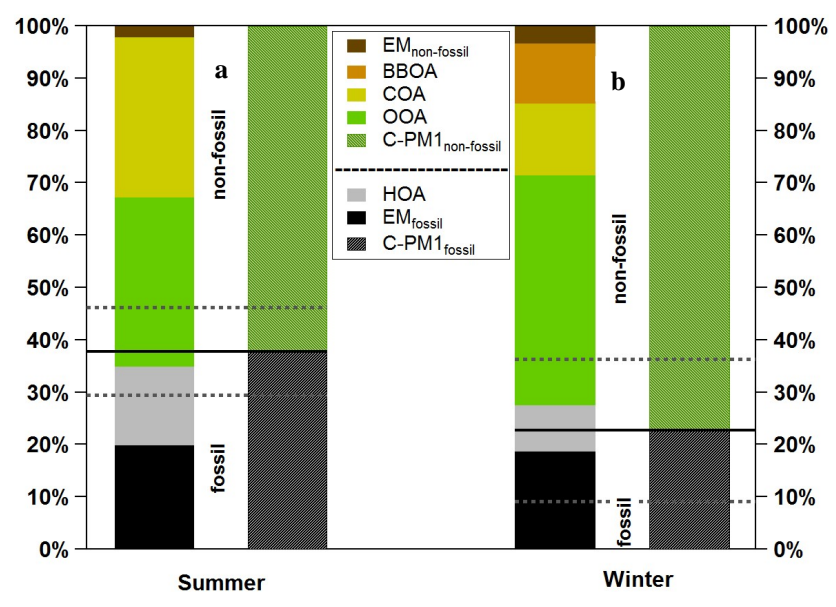

Figure 7. Combined analysis of AMS-derived $\mathrm{PM}_{1} \mathrm{OA}$ fractions and elemental carbon with results from fossil fuel and non-fossil fuel carbon ${ }^{14} \mathrm{C}$ analysis, for the summer (a) and the winter (b) campaign at the urban downtown site. The left columns for each season show the source apportionment from AMS and EC measurements, the right columns show the fossil fuel and non-fossil fuel fractions of carbonaceous $\mathrm{PM}_{1}$. Combined, both columns allow the attribution of the individual aerosol types to fossil fuel and non-fossil fuel parts. EM denotes elemental carbon matter, BBOA biomass burning OA, COA cooking OA, OOA oxygenated OA, HOA hydrocarbonlike OA (associated with road transport). The dashed lines represent the combined uncertainties of the ${ }^{14} \mathrm{C}$ measurement and the splits between OC and EC, fossil fuel and non-fossil fuel EM and OOA and their variability as a fractional contribution to carbonaceous $\mathrm{PM}_{1}$. Note that for wintertime, the fossil fuel EC and primary OA fractions identified from AMS-PMF analysis are somewhat larger than the total fossil fuel carbonaceous $\mathrm{PM}_{1}$ from the ${ }^{14} \mathrm{C}$ analysis, but agree within their uncertainties.

\section{Sources and origin of organic and inorganic aerosols}

The MEGAPOLI campaign results also provide important insights into specific sources of carbonaceous PM (the sum of $\mathrm{OA}$ and $\mathrm{BC}$ ), which represents on average almost $70 \%$ (summer) and $43 \%$ (winter) of $\mathrm{PM}_{1}$ at the urban background site. Radiocarbon $\left({ }^{14} \mathrm{C}\right)$ analysis clearly shows a dominant non-fossil fuel fraction of carbonaceous $\mathrm{PM}_{1}: \sim 62 \% \pm 8 \%$ (uncertainty) during summer and $\sim 78 \% \pm 14 \%$ during winter (Fig. 7). These values are much higher than those for other megacities reported in Hodzic et al. (2010), where contributions from non-fossil fuel carbon are about 30 and $40 \%$, respectively, during summer and winter for Tokyo, about $30 \%$ during summer for Los Angeles, about $30 \%$ during spring in Mexico City for days without significant contribution of wild-fires, and about 50 and $30 \%$ in summer and winter in Beijing, respectively. Thus sources of non-fossil fuel carbon are much more important for Paris than for many other megacities.

Cooking-related OA (e.g., modern carbon) constitutes up to $30 \%$ of carbonaceous $\mathrm{PM}_{1}$ in summer and nearly $15 \%$ 


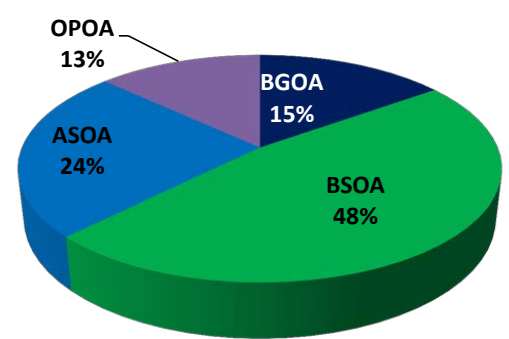

Figure 8. Contributions to secondary organic aerosol during the MEGAPOLI summer campaign period, simulated with the CHIMERE model: BGOA (background organic aerosol), BSOA (biogenic SOA), ASOA (anthropogenic SOA), OPOA (oxidized primary OA of anthropogenic origin). BSOA and BGOA are considered as of non-fossil fuel, ASOA and OPOA as of fossil fuel origin.

in winter. The high values at the urban site could be partly due to a large number of restaurants nearby, although the cooking source has also been identified at the SW suburban site (Crippa et al., 2013b) and in the Paris pollution plume (von der Weiden-Reinmüller et al., 2014a, b). This finding for Paris is consistent with the importance of cooking contributions found in several other cities (London (Allan et al., 2010), Barcelona (Mohr et al., 2012), Beijing (Huang et al., 2010), New York City (Sun et al., 2011), and Toronto (Slowik et al., 2010)).

During summer, the PMF OOA factor, a proxy for secondary organic aerosol (SOA), accounted for nearly $40 \%$ of OA. Combined ${ }^{14} \mathrm{C} / \mathrm{AMS}-\mathrm{PMF}$ analysis suggests that more than $90 \%$ of this OOA is of non-fossil fuel origin with an uncertainty range between 60 and $100 \%$ (Fig. 7). Secondary organic aerosol formation from non-fossil fuel precursors is thus clearly the dominant source for SOA advected to the Paris megacity during summer. Modeling results using CHIMERE including the volatility basis set (description in Sect. S5) confirm the origin of SOA: more than $60 \%$ of SOA is of non-fossil fuel and mostly biogenic origin, which is within, albeit at the lower end of, the experimentally derived range of values (see Fig. 8). The simulations indicate two transport patterns during high SOA periods in Paris: either transport from the northeast with SOA of mixed anthropogenic and biogenic origin, or transport from the south with predominantly biogenic SOA, from large biogenic VOC emissions over southwestern France and northeastern Spain (Zhang et al., 2013). Apparently, rapid SOA formation from anthropogenic VOC precursors, as for example observed in Mexico City (e.g., Volkamer et al., 2006), is not strong and fast enough within the Paris agglomeration to compete with the imported biogenic SOA fraction. However, SOA within the Paris pollution plume at about $100 \mathrm{~km}$ downwind of the city is enriched with anthropogenic SOA after several hours of processing time, based on the analysis of aircraft data obtained during the summer campaign (Freney et al., 2014). It should also be noted that alternative PMF calculations of

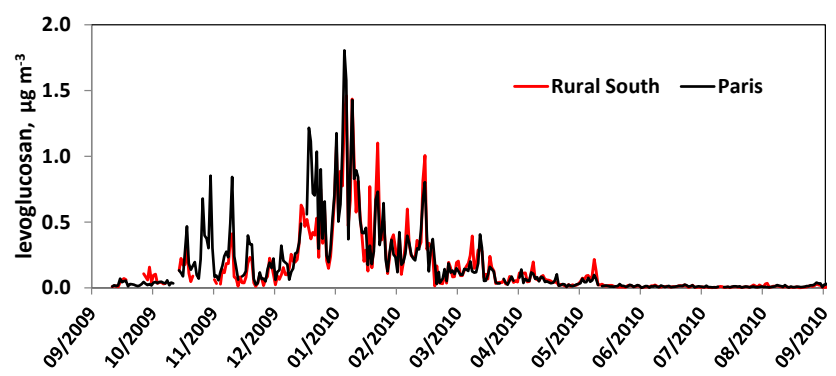

Figure 9. Daily levoglucosan values observed during the PARTICULES project from September 2009 to September 2010 at the downtown urban and southern rural sites. The rural site is located far from direct sources. Levoglucosan is a tracer for wood-burning emissions. The similar values at both sites $\left(R^{2}=0.83\right.$, slope rural vs. downtown site 0.84 ) suggest a strong regional control of woodburning-related organic aerosol.

summer campaign AMS data slightly alter the results. For instance, the five-factor PMF analysis for the urban background site shows an additional factor related to biogenic marine emissions with high sulfur content and contributing a little more than $10 \%$ to summer $\mathrm{PM}_{1}$ OA (Crippa et al., 2013c).

During winter, PMF analysis of AMS measurements directly attributes $12 \%$ of carbonaceous $\mathrm{PM}_{1}$ to wood burning. A large fraction (44\%) of carbonaceous $\mathrm{PM}_{1}$ is attributed to OOA (Fig. 7), similar to other megacities during winter (New York City and Tokyo (Zhang et al., 2007)). From the combined ${ }^{14} \mathrm{C} / \mathrm{AMS}-\mathrm{PMF}$ analysis, at least about $80 \%$ of this fraction is estimated to be of non-fossil fuel origin (Fig. 7). This points to either strong contributions of aged organic aerosol from wood burning or of SOA formation from biogenic VOCs, even if in wintertime biogenic emissions are expected to be much lower than during summer. Estimated wood burning contributions to OA from the Aethalometer model (Sandradewi et al., 2008) and a tracer approach (using levoglucosan as a tracer for wood-burning emissions) for this period are also compatible with a part of the identified OOA fraction originating from wood-burning emissions, within their large error bars (Crippa et al., 2013a). For instance Grieshop et al. (2009) and Heringa et al. (2011) showed that domestic wood-burning emissions from wood stoves form significant amounts of secondary organic aerosol. A question arises of the local versus regional origin of wood-burning OA in the Paris agglomeration since the dominant OA fraction was assigned to advection from outside in Sect. 3.1. The regional origin of primary or secondary wood-burning emissions is made evident by the strong correlation and similar levels of levoglucosan between the urban background and rural (southern) Paris sites of the PARTICULES project $\left(R^{2}=\right.$ 0.83, Fig. 9). However, more work is required at a regional scale to better separate wood-burning emissions from urban, suburban and rural areas. A large wood-burning contribution to OA (up to $60 \%$ during wintertime) was also found for the 
Grenoble agglomeration in the French Alps $(\sim 650000$ inhabitants) (Favez et al., 2010). In general, in Alpine valleys, wood-burning contributions to OA around $50 \%$ were found (Herich et al., 2014). Crippa et al. (2014) showed that woodand biomass-burning-related organic aerosol concentrations were significant across Europe even in spring and autumn.

Fossil fuel EC and HOA constitute about 20 and $15 \%$, respectively, of the carbonaceous $\mathrm{PM}_{1}$ in summer, and about 20 and $10 \%$, respectively, in winter (Fig. 7). According to emission inventories like those developed by MACC (Monitoring Atmospheric Composition and Climate, Pouliot et al., 2012) and EMEP (European Monitoring and Evaluation Program, Vestreng et al., 2007), the major contributor to this fossilfuel-related fraction is road transport. Unlike biomass burning emissions, these contributions are expected to be dominated by local emissions within the agglomeration. This is confirmed for example by simulations with the PMCAMx model which attribute about $60 \%$ of EC to emissions within the agglomeration (during the MEGAPOLI summer campaign).

The secondary inorganic aerosol fraction, mostly associated with regional transport ( $>70 \%$, see Sect. 3.2), represents about $30 \%$ of $\mathrm{PM}_{1}$ during summer (19\% sulfate, $6 \%$ nitrate and $7 \%$ ammonium) and more than $50 \%$ during winter (16\% sulfate, $28 \%$ nitrate and $12 \%$ ammonium). Again, MACC and EMEP emission inventories (Pouliot et al., 2012; Vestreng et al., 2007) indicate that inorganic aerosol precursors $\mathrm{SO}_{2}, \mathrm{NO}_{x}$ and $\mathrm{NH}_{3}$ are mainly of anthropogenic origin. $\mathrm{SO}_{2}$ is mostly emitted by industrial sources (including energy production) and shipping. $\mathrm{NO}_{x}$ emissions are dominated by transportation including shipping, while $\mathrm{NH}_{3}$ is mainly emitted by agriculture. Thus, unlike for organic aerosol with major non-fossil sources, transport- and industry-related fossil fuel combustion strongly contributes to fine inorganic PM. The dominant advected fraction of inorganic aerosol is explained by two factors: first, major source areas of its gaseous precursors are located outside the agglomeration (especially for $\mathrm{SO}_{2}$ and $\mathrm{NH}_{3}$ ); second, the time necessary for oxidation of the precursors does not allow for efficient aerosol formation from emissions within the megacity (as for nitrate formation from $\mathrm{NO}_{x}$ emissions).

\section{Comparison to other megacities}

The strong regional control of fine PM in Paris is here compared to the situation in other megacities. We use BC as a tracer for the local megacity contribution to fine PM. A compilation of urban background $\mathrm{BC}$ and $\mathrm{EC}$ measurements in several megacities (Fig. 10 and Table 1) shows that values for Paris $\left(1.8 \mu \mathrm{g} \mathrm{m}^{-3}\right)$ are at the lower end, within a cluster of megacities like Los Angeles, London, or New York City $\left(1-2 \mu \mathrm{g} \mathrm{m}^{-3}\right)$. Several American and Asian megacities have intermediate BC levels (Rio de Janeiro, Mexico City, Seoul, $3-5 \mu \mathrm{g} \mathrm{m}^{-3}$ ), while Asian megacities in fast devel-

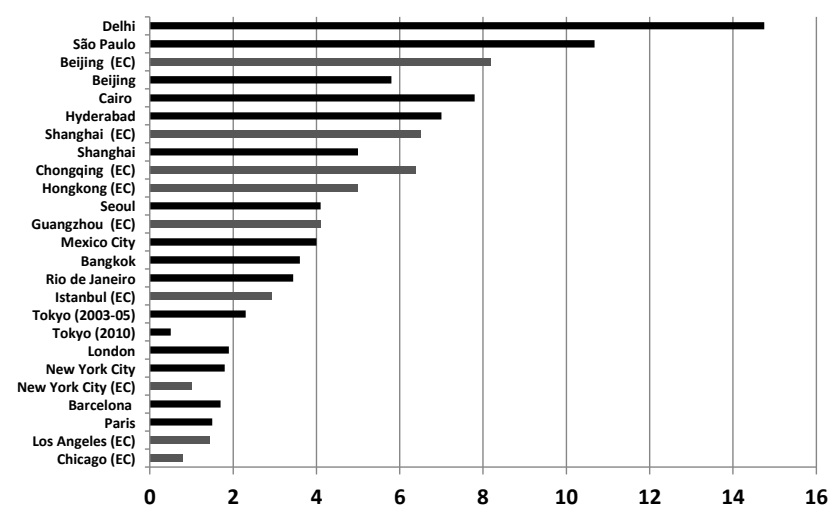

Figure 10. Concentrations of BC (black) and EC (grey) observed in megacities across the world. Note that Bangkok, Barcelona, Chicago, Chongqing, Hyderabad and London have fewer inhabitants (Table 1) than the 10 million accepted as a limit for megacities. The uncertainty due to differences in the measurement methods and in the representativeness for urban background conditions is estimated to be approximately $50 \%$ (Sect. S3 in the Supplement). References for the studies used here are given in Table 1.

oping countries (Beijing, Delhi, etc.) and Cairo display the largest values $\left(>6 \mu \mathrm{g} \mathrm{m}^{-3}\right)$. Despite uncertainties due to different measurement protocols (Bond et al., 2013; Petzold et al., 2013) and site representativeness (approximately a factor of 2, Sect. S2), the general tendency towards lower values in post-industrial megacities is clear. Nevertheless, since $\mathrm{BC}$ and associated compounds like polycyclic aromatic hydrocarbons are known to have strong adverse health effects (e.g., Janssen et al., 2012), BC still represents an important air quality problem even for megacities with lower concentrations like the densely populated Paris agglomeration.

During specific pollution episodes, high PM concentrations can also be encountered in the Paris agglomeration. For instance, during March 2014 (for 10 days from 7 to 18 March), exceptionally high $\mathrm{PM}_{10}$ concentrations exceeded pollution alert levels (daily average of $80 \mu \mathrm{g} \mathrm{m}^{-3}$ $\mathrm{PM}_{10}$ ) on several occasions. During this episode, anticyclonic conditions led to regional PM accumulation over northwestern Europe. ACSM measurements at the SIRTA site showed a prevailing contribution of ammonium nitrate $\left(\sim 50 \%\right.$ of $\left.\mathrm{PM}_{1}\right)$ and ammonium sulfate $(\sim 15 \%)$ suggesting a strong advective impact from outside the agglomeration, in line with the results of our study (Sciare, 2014). In addition, low dispersive conditions during this period also favored additional local pollution build-up.

London is another European megacity with expected low average local contributions to PM levels. Indeed, the regional contribution for organic aerosol, nitrate and sulfate was found to dominate based on observations during the REPARTEE (REgents PARk and Tower Environmental Experiment) campaigns in autumns 2006 and 2007 (Harrison et al., 2012), although a quantitative assessment could not be 
Table 1. Origin of black and elemental carbon data and observation periods used in Fig. 10, and megacity population in year 2015.

\begin{tabular}{|c|c|c|c|}
\hline City & Observation period & Reference & Population in 2015 (in $10^{6}$ ) \\
\hline Bangkok & Apr 2008-Mar 2008 & Sahu et al. (2011) & 9.27 \\
\hline Barcelona & Jan-Dec 2009 & Reche et al. (2011) & 5.26 \\
\hline \multirow[t]{3}{*}{ Beijing } & Aug 2004 & Gros et al. (2007) & 20.38 \\
\hline & Summer (Jul-Aug 2001; Jun-Jul 2002) & Dan et al. (2004) & \\
\hline & Winter (Dec 2001-Jan 2002 and Dec 2002); & & \\
\hline Beiijing (EC) & $\begin{array}{l}\text { Spring (Mar 2003). } \\
\text { Mar 2005-Feb } 2006\end{array}$ & Yang et al. (2011) & \\
\hline Cairo & Mar-Apr 2005 & Favez et al. (2008) & 18.77 \\
\hline Chicago & Jan 2005-Dec 2008 & Hand et al. (2011) & 8.75 \\
\hline Chongqing & Mar 2005-Feb 2006 & Yang et al. (2011) & 13.33 \\
\hline Delhi & Jan 2006-Jan 2007 & Bano et al. (2011) & 25.7 \\
\hline Guangzhou & Dec 2008-Feb 2009 & Yang et al. (2011) & 12.46 \\
\hline Hyderabad & Jan-Dec 2003 & Latha and Badarinath (2005) & 8.94 \\
\hline Hong Kong & Nov 2000-Feb 2001 and Jun-Aug 2001 & Ho et al. (2006) & 7.31 \\
\hline Istanbul & Nov 2007-Jun 2009 & Theodosi et al. (2010) & 14.16 \\
\hline London & Jan-Dec 2009 & Reche et al. (2011) & 10.31 \\
\hline Los Angeles & Jan 2005-Dec 2008 & Hand et al. (2011) & 12.31 \\
\hline Mexico City & Mar 2006 & Aiken et al. (2008) & 21.0 \\
\hline New York City & 2006-2008 & Rattigan et al. (2011) & 18.99 \\
\hline Paris & Sep 2009-Sep 2010 & This study & 10.84 \\
\hline Rio de Janeiro & Jun 2007-Aug 2008 & Miranda et al. (2012) & 12.9 \\
\hline São Paulo & Jun 2007-Aug 2008 & Miranda et al. (2012) & 21.07 \\
\hline Seoul & $2003-2004$ & Kim et al. (2007) & 9.77 \\
\hline Shanghai & Mar 1999-May 2000 & Ye et al. (2003) & 23.74 \\
\hline Tokyo & $2003-2005,2010$ & Kondo et al. (2012) & 38.0 \\
\hline
\end{tabular}

made with the available data at only one central London site. These dominant regional and correspondingly smaller local emission contributions to urban background PM levels are reflected in recently revised emission inventories. For both the Paris and London agglomerations, bottom-up emission inventories using geographically specific information on activity and emission factors yield about a factor of 3 lower per capita emission values for BC and PM than for national averages (Timmermans et al., 2013), due to lower per capita fuel consumption for large cities with increased population density (Grimm et al., 2008), and possibly also due to lower emission factors.

In contrast, Mexico City is a good example of a megacity with larger local pollution impact. PMCAMx simulations for the MILAGRO campaign in March 2006 (Molina et al., 2010) indicated a much higher contribution of local emissions to fine PM for Mexico City $\left(60 \%\right.$ for $\mathrm{PM}_{2.5}, 60 \%$ for OA, $80 \%$ for nitrate, less than $10 \%$ for sulfate (Karydis et al., 2011)) than for Paris (Figs. 5 and 6). Mexico City is surrounded by mountain ridges, leading to less favorable dispersion conditions with average summer wind speed of about $4 \mathrm{~m} \mathrm{~s}^{-1}$ during MILAGRO at about $300 \mathrm{~m}$ a.g.l. (Fast et al., 2007) as compared to about $8 \mathrm{~ms}^{-1}$ in Paris during both the MEGAPOLI summer and winter campaign (from SODAR measurements at the SW suburban site at $200 \mathrm{~m}$ a.g.1.). Also, increased radiation intensity (enhancing the build-up of secondary pollutants already within the agglomeration), and higher per capita emissions than for Paris (consistent with larger BC values, Fig. 10) contribute to this enhanced local pollution impact. These different conditions result in a local $\mathrm{PM}_{2.5}$ contribution of about $1.4 \mu \mathrm{g} \mathrm{m}^{-3}$ per million inhabitants for Mexico City with 21 million inhabitants (United Nations, 2015) simulated during MILAGRO, but only $0.3 \mu \mathrm{g} \mathrm{m}^{-3}$ per million inhabitants for Paris (with 10.84 million inhabitants), observed on an annual average basis during PARTICULES. Thus, in terms of local versus advected contributions to PM, these two megacities might be two extremes.

\section{Conclusions}

Analysis of the MEGAPOLI and PARTICULES campaign observations of satellite data and of modeling results have allowed for the quantification of the advected/regional versus local origin of particulate matter (PM) and especially carbonaceous aerosol in the Paris agglomeration. On average over 1 year, about $70 \%$ of the fine PM mass is transported into the megacity from upwind regions of France and continental Europe. Note that this number refers to urban background. For traffic sites, the local contribution would be larger. For organic aerosol (OA) and nitrate, also more than 
$70 \%$ of their urban background concentrations, respectively, are advected to Paris. For high PM periods, the advected fractions can be even larger. At a measurement site located at the NE edge of the agglomeration, the strong advective source caused higher PM levels for air masses originating in the NE sector (continental origin) than those originating in $\mathrm{SW}$, and thus having crossed the agglomeration before arriving at the site. Satellite AOD measurements and chemistry-transport modeling simulations further confirm these results.

In contrast to other megacities, primary fossil fuel combustion emissions constitute little of carbonaceous fine PM: less than about $20 \%$ in winter and less than $40 \%$ in summer. Instead, cooking activities and, during winter, residential wood burning are the major primary organic PM sources and contribute to non-fossil fuel aerosol. From combined ${ }^{14} \mathrm{C}$ and PMF analysis of AMS data, a mainly non-fossil fuel origin of secondary organic aerosol can be inferred both during summer and winter, either due to formation of secondary aerosol from biogenic VOC precursors or to processing of wood-burning emissions.

Low BC/EC levels (in comparison to those at other megacities worldwide, and not precluding large episodic $\mathrm{BC}$ and PM levels) are consistent with relatively low emissions in a post-industrial megacity such as Paris. Indeed, more efficient per capita energy use, and lower emission factors than on national average contribute to these low emissions. Other post-industrial, mid-latitude, flat terrain megacities like New York City, London, and Tokyo probably show a similar type of behavior, while local sources prevail for megacities such as Mexico City or Los Angeles, affected by one or several factors such as larger local emissions, dispersion limited by orography and larger radiation.

\section{The Supplement related to this article is available online at doi:10.5194/acp-15-9577-2015-supplement.}

Acknowledgements. This research in the context of the MEGAPOLI project is financially supported by the European Community's Framework Program FP/2007-2011 under grant agreement no. 212520. Support from the French ANR project MEGAPOLI - PARIS (ANR-09-BLAN-0356), from the CNRSINSU/FEFE via l'ADEME (no. 0962c0018) and via support of publication fees, the Ile de France/SEPPE as well as from internal Max Planck Institute for Chemistry funds are acknowledged. We are very grateful for the strong logistical support in the field by IPSL/SIRTA, by Laboratoire d'Hygiène de la Ville de Paris (LHVP) and by the staff of the Golf Départemental de la Poudrerie. In addition, we thank the teams of participating laboratories for support during the campaign.

Edited by: C. Reeves

\section{References}

Aiken, A. C., Decarlo, P. F., Kroll, J. H., Worsnop, D. R., Huffman, J. A., Docherty, K. S., Ulbrich I. M., Mohr, C., Kimmel, J. R., Sueper, D., Sun, Y., Zhang, Q., Trimborn, A., Northway, M., Ziemann, P. J., Canagaratna, M. R., Onasch, T. B., Alfarra, M. R., Prevot, A. S., Dommen, J., Duplissy, J., Metzger, A., Baltensperger, U., and Jimenez, J. L.: O/C and OM/OC ratios of primary, secondary, and ambient organic aerosols with high-resolution time-of-flight aerosol mass spectrometry, Environ. Sci. Technol., 42, 4478-4485, 2008.

Allan, J. D., Williams, P. I., Morgan, W. T., Martin, C. L., Flynn, M. J., Lee, J., Nemitz, E., Phillips, G. J., Gallagher, M. W., and Coe, H.: Contributions from transport, solid fuel burning and cooking to primary organic aerosols in two UK cities, Atmos. Chem. Phys., 10, 647-668, doi:10.5194/acp-10-647-2010, 2010.

Baklanov, A., Lawrence, M., Pandis, S., Mahura, A., Finardi, S., Moussiopoulos, N., Beekmann, M., Laj, P., Gomes, L., Jaffrezo, J.-L., Borbon, A., Coll, I., Gros, V., Sciare, J., Kukkonen, J., Galmarini, S., Giorgi, F., Grimmond, S., Esau, I., Stohl, A., Denby, B., Wagner, T., Butler, T., Baltensperger, U., Builtjes, P., van den Hout, D., van der Gon, H. D., Collins, B., Schluenzen, H., Kulmala, M., Zilitinkevich, S., Sokhi, R., Friedrich, R., Theloke, J., Kummer, U., Jalkinen, L., Halenka, T., Wiedensholer, A., Pyle, J., and Rossow, W. B.: MEGAPOLI: concept of multi-scale modelling of megacity impact on air quality and climate, Adv. Sci. Res. 4, 115-120, 2010.

Bano, T., Singh, S., Gupta, N. C., Soni, K., Tanwar, R. S., Nath, S., Arya, B. C., and Gera, B. S.: Variation in aerosol black carbon concentration and its emission estimates at the mega-city Delhi, Int. J. Remote Sens., 32, 6749-6764, 2011.

Beirle S., Boersma, K. F., Platt, U., Lawrence, M. G., and Wagner, T.: Megacity emissions and lifetimes of nitrogen oxides probed from space, Science, 333, 1737-1739, 2011.

Bond, T. C., Doherty, S. J., Fahey, D. W., Forster, P. M., Berntsen, T., DeAngelo, B. J., Flanner, M. G., Ghan, S., Kärcher, B., Koch, D., Kinne, S., Kondo, Y., Quinn, P. K., Sarofim, M. C., Schultz, M. G., Schulz, M., Venkataraman, C., Zhang, H., Zhang, S., Bellouin, N., Guttikunda, S. K., Hopke, P. K., Jacobson, M. Z., Kaiser, J. W., Klimont, Z., Lohmann, U., Schwarz, J. P., Shindell, D., Storelvmo, T., Warren, S. G., and Zender, C. S.: Bounding the role of black carbon in the climate system: A scientific assessment, J. Geophys. Res.-Atmos., 118, 5380-5552, 2013.

Bressi, M., Sciare, J., Ghersi, V., Bonnaire, N., Nicolas, J. B., Petit, J.-E., Moukhtar, S., Rosso, A., Mihalopoulos, N., and Féron, A.: A one-year comprehensive chemical characterisation of fine aerosol $\left(\mathrm{PM}_{2.5}\right)$ at urban, suburban and rural background sites in the region of Paris (France), Atmos. Chem. Phys., 13, 78257844, doi:10.5194/acp-13-7825-2013, 2013.

Bressi, M., Sciare, J., Ghersi, V., Mihalopoulos, N., Petit, J.-E., Nicolas, J. B., Moukhtar, S., Rosso, A., Féron, A., Bonnaire, N., Poulakis, E., and Theodosi, C.: Sources and geographical origins of fine aerosols in Paris (France), Atmos. Chem. Phys., 14, 8813-8839, doi:10.5194/acp-14-8813-2014, 2014.

Butler, D.: Megacity project seeks to gauge urban pollution, Nature, 455, 142-143, 2008.

Cavalli, F., Viana, M., Yttri, K. E., Genberg, J., and Putaud, J.-P.: Toward a standardised thermal-optical protocol for measuring atmospheric organic and elemental carbon: the EUSAAR proto- 
col, Atmos. Meas. Tech., 3, 79-89, doi:10.5194/amt-3-79-2010, 2010

Chan, C. K. and Yao, X. H.: Air pollution in mega cities in China, Atmos. Environ., 42, 1-42, 2008.

Couvidat, F., Kim, Y., Sartelet, K., Seigneur, C., Marchand, N., and Sciare, J.: Modeling secondary organic aerosol in an urban area: application to Paris, France, Atmos. Chem. Phys., 13, 983-996, doi:10.5194/acp-13-983-2013, 2013.

Crippa, M., Canonaco, F., Slowik, J. G., El Haddad, I., DeCarlo, P. F., Mohr, C., Heringa, M. F., Chirico, R., Marchand, N., Temime-Roussel, B., Abidi, E., Poulain, L., Wiedensohler, A., Baltensperger, U., and Prévôt, A. S. H.: Primary and secondary organic aerosol origin by combined gas-particle phase source apportionment, Atmos. Chem. Phys., 13, 8411-8426, doi:10.5194/acp-13-8411-2013, 2013a.

Crippa, M., DeCarlo, P. F., Slowik, J. G., Mohr, C., Heringa, M. F., Chirico, R., Poulain, L., Freutel, F., Sciare, J., Cozic, J., Di Marco, C. F., Elsasser, M., Nicolas, J. B., Marchand, N., Abidi, E., Wiedensohler, A., Drewnick, F., Schneider, J., Borrmann, S., Nemitz, E., Zimmermann, R., Jaffrezo, J.-L., Prévôt, A. S. H., and Baltensperger, U.: Wintertime aerosol chemical composition and source apportionment of the organic fraction in the metropolitan area of Paris, Atmos. Chem. Phys., 13, 961-981, doi:10.5194/acp-13-961-2013, 2013b.

Crippa, M., El Haddad, I., Slowik, J. G., DeCarlo, P. F., Mohr, C., Heringa, M. F., Chirico, R., Marchand, N., Sciare, J., Baltensperger, U., and Prévôt, A. S. H.: Identification of marine and continental aerosol sources in Paris using high resolution aerosol mass spectrometry, J. Geophys. Res., 118, 1950-1963, 2013c.

Crippa, M., Canonaco, F., Lanz, V. A., Äijälä, M., Allan, J. D., Carbone, S., Capes, G., Ceburnis, D., Dall'Osto, M., Day, D. A., DeCarlo, P. F., Ehn, M., Eriksson, A., Freney, E., Hildebrandt Ruiz, L., Hillamo, R., Jimenez, J. L., Junninen, H., Kiendler-Scharr, A., Kortelainen, A.-M., Kulmala, M., Laaksonen, A., Mensah, A. A., Mohr, C., Nemitz, E., O'Dowd, C., Ovadnevaite, J., Pandis, S. N., Petäjä, T., Poulain, L., Saarikoski, S., Sellegri, K., Swietlicki, E., Tiitta, P., Worsnop, D. R., Baltensperger, U., and Prévôt, A. S. H.: Organic aerosol components derived from 25 AMS data sets across Europe using a consistent ME-2 based source apportionment approach, Atmos. Chem. Phys., 14, 61596176, doi:10.5194/acp-14-6159-2014, 2014.

Dan, M., Zhuang, G., Li, X., Tao, H., and Zhuang, Y.: The characteristics of carbonaceous species and their sources in $\mathrm{PM}_{2.5}$ in Beijing, Atmos. Environ., 38, 3443-3452, 2004.

DeCarlo, P. F., Kimmel, J. R., Trimborn, A., Northway, M. J., Jayne, J. T., Aiken, A. C., Gonin, M., Fuhrer, K., Horvath, T., Docherty, K. S., Worsnop, D. R., and Jimenez, J. L.: Field-deployable, high-resolution, time-of-flight aerosol mass spectrometer, Analyt. Chemistry, 78, 8281-8289, 2006.

Draxler, R. R. and Hess, G. D.: Description of the HYSPLIT_4 modeling system. NOAA Tech. Memo. ERL ARL-224, NOAA Air Resources Laboratory, Silver Spring, MD, 24 p., 1997.

Drewnick, F., Hings, S. S., DeCarlo, P., Jayne, J. T., Gonin, M., Fuhrer, K., Weimer, S., Jimenez, J. L., Demerjian, K. L., Borrmann, S., and Worsnop, D. R.: A new time-of-flight aerosol mass spectrometer (ToF-AMS) - instrument description and first field deployment, Aerosol Sci. Technol., 39, 637-658, 2005.
Dutkiewicz, V. A., Qureshi, S., Khana, A. R., Ferraro, V., Schwab, J., Demerjian, K., and Husain, L.: Sources of fine particulate sulfate in New York, Atmos. Environ., 38, 3179-3189, 2004.

El Haddad, I., D’Anna, B., Temime-Roussel, B., Nicolas, M., Boreave, A., Favez, O., Voisin, D., Sciare, J., George, C., Jaffrezo, J.-L., Wortham, H., and Marchand, N.: Towards a better understanding of the origins, chemical composition and aging of oxygenated organic aerosols: case study of a Mediterranean industrialized environment, Marseille, Atmos. Chem. Phys., 13, 78757894, doi:10.5194/acp-13-7875-2013, 2013.

Fast, J. D., de Foy, B., Acevedo Rosas, F., Caetano, E., Carmichael, G., Emmons, L., McKenna, D., Mena, M., Skamarock, W., Tie, X., Coulter, R. L., Barnard, J. C., Wiedinmyer, C., and Madronich, S.: A meteorological overview of the MILAGRO field campaigns, Atmos. Chem. Phys., 7, 2233-2257, doi:10.5194/acp-7-2233-2007, 2007.

Favez, O., Cachier, H., Sciare, J., El-Araby, T. M., Alfaro, S., Harhash, M. A., and Abdel Wahab, M. M.: Seasonality of major aerosol species in Greater Cairo (Egypt), Atmos. Environ., 42, 1503-1516, 2008.

Favez, O., El Haddad, I., Piot, C., Boréave, A., Abidi, E., Marchand, N., Jaffrezo, J.-L., Besombes, J.-L., Personnaz, M.-B., Sciare, J., Wortham, H., George, C., and D'Anna, B.: Inter-comparison of source apportionment models for the estimation of wood burning aerosols during wintertime in an Alpine city (Grenoble, France), Atmos. Chem. Phys., 10, 5295-5314, doi:10.5194/acp-10-52952010, 2010.

Freney, E. J., Sellegri, K., Canonaco, F., Colomb, A., Borbon, A., Michoud, V., Doussin, J.-F., Crumeyrolle, S., Amarouche, N., Pichon, J.-M., Bourianne, T., Gomes, L., Prevot, A. S. H., Beekmann, M., and Schwarzenböeck, A.: Characterizing the impact of urban emissions on regional aerosol particles: airborne measurements during the MEGAPOLI experiment, Atmos. Chem. Phys., 14, 1397-1412, doi:10.5194/acp-14-1397-2014, 2014.

Freutel, F., Schneider, J., Drewnick, F., von der Weiden-Reinmüller, S.-L., Crippa, M., Prévôt, A. S. H., Baltensperger, U., Poulain, L., Wiedensohler, A., Sciare, J., Sarda-Estève, R., Burkhart, J. F., Eckhardt, S., Stohl, A., Gros, V., Colomb, A., Michoud, V., Doussin, J. F., Borbon, A., Haeffelin, M., Morille, Y., Beekmann, M., and Borrmann, S.: Aerosol particle measurements at three stationary sites in the megacity of Paris during summer 2009: meteorology and air mass origin dominate aerosol particle composition and size distribution, Atmos. Chem. Phys., 13, 933-959, doi:10.5194/acp-13-933-2013, 2013.

Ghersi V., Rosso, A., Moukthar, S., Leger, K., Sciare, J., Bressi, M., Ferron, A., and Bonnaire, N.: A comprehensive source apportionment study of fine aerosols $\left(\mathrm{PM}_{2.5}\right)$ in the region of Paris, France, Pollution Atmosphérique, Numéro Spécial, 63-72, 2010.

Grimm, N. B., Faeth, S. H., Golubiewski, N. E., Redman, C. L., Wu, J., Bai, X., and Briggs, J. M.: Global change and the ecology of cities, Science, 319, 756-760, 2008.

Grieshop, A. P., Logue, J. M., Donahue, N. M., and Robinson, A. L.: Laboratory investigation of photochemical oxidation of organic aerosol from wood fires 1: measurement and simulation of organic aerosol evolution, Atmos. Chem. Phys., 9, 1263-1277, doi:10.5194/acp-9-1263-2009, 2009.

Gros, V., Sciare, J., and Tong Yu: Air-quality measurements in megacities: Focus on gaseous organic and particulate pollutants 
and comparison between two contrasted cities, Paris and Beijing, C. R. Geoscience, 339, 764-774, 2007.

Gurjar, B. R. and Lelieveld, J.: New directions: megacities and global change, Atmos. Environ., 39, 391-393, 2005.

Gurjar, B. R., Jain, A., Sharma, A., Agarwal, A., Gupta, P., Nagpure, A. S., and Lelieveld, J.: Human health risksin megacities due to air pollution, Atmos. Environ., 44, 4606-4613, 2010.

Haeffelin, M., Barthès, L., Bock, O., Boitel, C., Bony, S., Bouniol, D., Chepfer, H., Chiriaco, M., Cuesta, J., Delanoë, J., Drobinski, P., Dufresne, J.-L., Flamant, C., Grall, M., Hodzic, A., Hourdin, F., Lapouge, F., Lemaître, Y., Mathieu, A., Morille, Y., Naud, C., Noël, V., O'Hirok, W., Pelon, J., Pietras, C., Protat, A., Romand, B., Scialom, G., and Vautard, R.: SIRTA, a ground-based atmospheric observatory for cloud and aerosol research, Ann. Geophys., 23, 253-275, doi:10.5194/angeo-23-253-2005, 2005.

Hallquist, M., Wenger, J. C., Baltensperger, U., Rudich, Y., Simpson, D., Claeys, M., Dommen, J., Donahue, N. M., George, C., Goldstein, A. H., Hamilton, J. F., Herrmann, H., Hoffmann, T., Iinuma, Y., Jang, M., Jenkin, M. E., Jimenez, J. L., Kiendler-Scharr, A., Maenhaut, W., McFiggans, G., Mentel, Th. F., Monod, A., Prévôt, A. S. H., Seinfeld, J. H., Surratt, J. D., Szmigielski, R., and Wildt, J.: The formation, properties and impact of secondary organic aerosol: current and emerging issues, Atmos. Chem. Phys., 9, 5155-5236, doi:10.5194/acp-9-51552009, 2009.

Hand, J. L., Copeland, S. A., Day, D. E., Dillner, A. M., Indresand, H., Malm, W. C., McDade, C. E., Moore, C. T., Pitchford, M. L., Schichtel, B. A., and Watson, J. G.: Spatial and seasonal patterns and temporal variability of haze and its constituents in the United States: IMPROVE Report V, June 2011, available at: http://vista.cira.colostate.edu/IMPROVE/Publications/ (last access: July 2015), 2011.

Harrison, R. M., Dall'Osto, M., Beddows, D. C. S., Thorpe, A. J., Bloss, W. J., Allan, J. D., Coe, H., Dorsey, J. R., Gallagher, M., Martin, C., Whitehead, J., Williams, P. I., Jones, R. L., Langridge, J. M., Benton, A. K., Ball, S. M., Langford, B., Hewitt, C. N., Davison, B., Martin, D., Petersson, K. F., Henshaw, S. J., White, I. R., Shallcross, D. E., Barlow, J. F., Dunbar, T., Davies, F., Nemitz, E., Phillips, G. J., Helfter, C., Di Marco, C. F., and Smith, S.: Atmospheric chemistry and physics in the atmosphere of a developed megacity (London): an overview of the REPARTEE experiment and its conclusions, Atmos. Chem. Phys., 12, 3065-3114, doi:10.5194/acp-12-3065-2012, 2012.

Herich, H., Gianini, M., Piot, C., Mocnik, G., Jaffrezo, J. L., Prévôt, A. S. H., and Hueglin, C.: Overview of the impact of wood burning emissions on carbonaceous aerosols and PM in large territory of the Alpine region, Atmos. Environ., 89, 64-75, 2014.

Heringa, M. F., DeCarlo, P. F., Chirico, R., Tritscher, T., Dommen, J., Weingartner, E., Richter, R., Wehrle, G., Prévôt, A. S. H., and Baltensperger, U.: Investigations of primary and secondary particulate matter of different wood combustion appliances with a high-resolution time-of-flight aerosol mass spectrometer, Atmos. Chem. Phys., 11, 5945-5957, doi:10.5194/acp-11-59452011, 2011.

Ho, K. F., Lee, S. C., Cao, J. J., Li, Y. S., Chow, J. C., Watson, J. G., and Fung, K.: Variability of organic and elemental carbon, water soluble organic carbon, and isotopes in Hong Kong, Atmos. Chem. Phys., 6, 4569-4576, doi:10.5194/acp-6-4569-2006, 2006.
Hodzic, A., Jimenez, J. L., Prévôt, A. S. H., Szidat, S., Fast, J. D., and Madronich, S.: Can 3-D models explain the observed fractions of fossil and non-fossil carbon in and near Mexico City?, Atmos. Chem. Phys., 10, 10997-11016, doi:10.5194/acp10-10997-2010, 2010.

Huang, X.-F., He, L.-Y., Hu, M., Canagaratna, M. R., Sun, Y., Zhang, Q., Zhu, T., Xue, L., Zeng, L.-W., Liu, X.-G., Zhang, Y.-H., Jayne, J. T., Ng, N. L., and Worsnop, D. R.: Highly time-resolved chemical characterization of atmospheric submicron particles during 2008 Beijing Olympic Games using an Aerodyne High-Resolution Aerosol Mass Spectrometer, Atmos. Chem. Phys., 10, 8933-8945, doi:10.5194/acp-10-8933-2010, 2010.

Janssen N. A. H., Gerlofs-Nijland, M. E., Lanki, T., Salonen, R. O., Cassee, F., Hoek, G., Fischer, P., Brunekreef, P., and Krzyzanowski, M.: Health effects of black carbon. WHO Regional Office for Europe, World Health Organization, Copenhagen, 1-96, 2012.

Jimenez, J. L., Canagaratna, M. R., Donahue, N. M., Prevot, A. S. H., Zhang, Q., Kroll, J. H., DeCarlo, P. F., Allan, J. D., Coe, H., Ng, N. L., Aiken, A. C., Docherty, K. S., Ulbrich, I. M., Grieshop, A. P., Robinson, A. L., Duplissy, J., Smith, J. D., Wilson, K. R., Lanz, V. A., Hueglin, C., Sun, Y. L., Tian, J., Laaksonen, A., Raatikainen, T., Rautiainen, J., Vaattovaara, P., Ehn, M., Kulmala, M., Tomlinson, J. M., Collins, D. R., Cubison, M J., Dunlea, E. J., Human, J. A., Onasch, T. B., Alfarra, M. R., Williams, P. I., Bower, K., Kondo, Y., Schneider, J., Drewnick, F., Borrmann, S., Weimer, S., Demerjian, K., Salcedo, D., Cottrell, L., Grin, R., Takami, A., Miyoshi, T., Hatakeyama, S., Shimono, A., Sun, J. Y., Zhang, Y. M., Dzepina, K., Kimmel, J. R., Sueper, D., Jayne, J. T., Herndon, S. C., Trimborn, A. M., Williams, L. R., Wood, E. C., Middlebrook, A. M., Kolb, C. E., Baltensperger, U., and Worsnop, D. R.: Evolution of Organic Aerosols in the Atmosphere, Science, 326, 1525-1529, 2009.

Karydis, V. A., Tsimpidi, A. P., Lei, W., Molina, L. T., and Pandis, S. N.: Formation of semivolatile inorganic aerosols in the Mexico City Metropolitan Area during the MILAGRO campaign, Atmos. Chem. Phys., 11, 13305-13323, doi:10.5194/acp11-13305-2011, 2011.

Kim, H. S., Huh, J. B., Hopke, P. K., Holsen, T. M., and Yi, S. M.: Characteristics of the major chemical constituents of $\mathrm{PM}_{2.5}$ and smog events in Seoul, Korea in 2003 and 2004, Atmos. Environ., 41, 6762-6770, 2007.

Kondo, Y., Ram, K., Takegawa, N., Salu, L., Morino, Y., Liu, X., and Ohara T., Reduction of black carbon aerosols in Tokyo: Comparison of real-time observations with emission estimates, Atmos. Environ., 54, 242-249, 2012.

Lall, R. and Thurston, G. D.: Identifying and quantifying transported vs. local sources of New York city $\mathrm{PM}_{2.5}$ fine particulate matter air pollution, Atmos. Environ., 40, 333-346, 2006.

Lanz, V. A., Alfarra, M. R., Baltensperger, U., Buchmann, B., Hueglin, C., and Prévôt, A. S. H.: Source apportionment of submicron organic aerosols at an urban site by factor analytical modelling of aerosol mass spectra, Atmos. Chem. Phys., 7, 15031522, doi:10.5194/acp-7-1503-2007, 2007.

Latha, K. M. and Badarinath, K. V. S.: Seasonal variations of black carbon aerosols and total aerosol mass concentrations over urban environment in India, Atmos. Environ., 39, 4129-4141, 2005. 
Lenschow, P., Abraham, H. J., Kutzner, K., Lutz, M., Preuß, J. D., and Reichenbächer, W.: Some ideas about the sources of $\mathrm{PM}_{10}$, Atmos. Environ., 35, 23-33, 2001.

Minguillón, M. C., Perron, N., Querol, X., Szidat, S., Fahrni, S. M., Alastuey, A., Jimenez, J. L., Mohr, C., Ortega, A. M., Day, D. A., Lanz, V. A., Wacker, L., Reche, C., Cusack, M., Amato, F., Kiss, G., Hoffer, A., Decesari, S., Moretti, F., Hillamo, R., Teinilä, K., Seco, R., Peñuelas, J., Metzger, A., Schallhart, S., Müller, M., Hansel, A., Burkhart, J. F., Baltensperger, U., and Prévôt, A. S. H.: Fossil versus contemporary sources of fine elemental and organic carbonaceous particulate matter during the DAURE campaign in Northeast Spain, Atmos. Chem. Phys., 11, 12067-12084, doi:10.5194/acp-11-12067-2011, 2011.

Miranda, R., Andrade, M. F., Fornaro, A., André, P. A., and Saldiva, P. H., Urban air pollution: a representative survey of $\mathrm{PM}_{2.5}$ mass concentrations in six Brazilian cities, Air Qual. Atmos. Health, 5, 63-77, 2012.

Mohr, C., DeCarlo, P. F., Heringa, M. F., Chirico, R., Slowik, J. G., Richter, R., Reche, C., Alastuey, A., Querol, X., Seco, R., Peñuelas, J., Jiménez, J. L., Crippa, M., Zimmermann, R., Baltensperger, U., and Prévôt, A. S. H.: Identification and quantification of organic aerosol from cooking and other sources in Barcelona using aerosol mass spectrometer data, Atmos. Chem. Phys., 12, 1649-1665, doi:10.5194/acp-12-1649-2012, 2012.

Molina, L. T., Madronich, S., Gaffney, J. S., Apel, E., de Foy, B., Fast, J., Ferrare, R., Herndon, S., Jimenez, J. L., Lamb, B., Osornio-Vargas, A. R., Russell, P., Schauer, J. J., Stevens, P. S., Volkamer, R., and Zavala, M.: An overview of the MILAGRO 2006 Campaign: Mexico City emissions and their transport and transformation, Atmos. Chem. Phys., 10, 8697-8760, doi:10.5194/acp-10-8697-2010, 2010

Molina, M. J. and Molina, L. T.: Megacities and atmospheric pollution, Air Waste Manage. Assoc., 54, 644-680, 2004.

Paatero, P. and Tapper, U.: Positive matrix factorization - a nonnegative factor model with optimal utilization of error-estimates of data values, Environmetrics, 5, 111-126, 1994.

Parrish, D. D., Singh, B. H., and Molina, L. T.: Air quality progress in North American megacities: A review, Atmos. Environ., 45, 7015-7025, 2011.

Petetin, H., Beekmann, M., Sciare, J., Bressi, M., Rosso, A., Sanchez, O., and Ghersi, V.: A novel model evaluation approach focusing on local and advected contributions to urban $\mathrm{PM}_{2.5}$ levels - application to Paris, France, Geosci. Model Dev., 7, 14831505, doi:10.5194/gmd-7-1483-2014, 2014.

Petit, J.-E.: Compréhension des sources et des processus de formation de la pollution particulaire en région Ile-de-France, Thèse de Doctorat de l'Université Versailles Saint Quentin en Yvelines, Versailles, November 2014

Petit, J.-E., Favez, O., Sciare, J., Crenn, V., Sarda-Estève, R., Bonnaire, N., Mocnik, G., Dupont, J.-C., Haeffelin, M., and LeozGarziandia, E.: Two years of near real-time chemical composition of submicron aerosols in the region of Paris using an Aerosol Chemical Speciation Monitor (ACSM) and a multiwavelength Aethalometer, Atmos. Chem. Phys., 15, 2985-3005, doi:10.5194/acp-15-2985-2015, 2015.

Petzold, A., Ogren, J. A., Fiebig, M., Laj, P., Li, S.-M., Baltensperger, U., Holzer-Popp, T., Kinne, S., Pappalardo, G., Sugimoto, N., Wehrli, C., Wiedensohler, A., and Zhang, X.-Y.: Recommendations for reporting "black carbon" measurements, At- mos. Chem. Phys., 13, 8365-8379, doi:10.5194/acp-13-83652013, 2013.

Pouliot, G., Pierce, T,. Denier van der Gon, H., Schaap, M., and Nopmongcol, U.: Comparing emissions inventories and modelready emissions datasets between Europe and North America for the AQMEII Project, Atmos. Environ., 53, 4-14, 2012.

Putaud, J. P., Van Dingenen, R., Alastuey, A., Bauer, H., Birmili, W., Cyrys, J., Flentje, H., Fuzzi, S., Gehrig, R., Hansson, H. C., Harrison, R. M., Herrmann, H., Hitzenberger, R., Hüglin, C., Jones, A. M., Kasper-Giebl, A., Kiss, G., Kousa, A., Kuhlbusch, T. A. J., Löschau, G., Maenhaut, W., Molnar, A., Moreno, T., Pekkanen, J., Perrino, C., Pitz, M., Puxbaum, H., Querol, X., Rodríguez, S., Salma, I., Schwarz, J., Smolik, J., Schneider, J., Spindler, G., ten Brink, H., Tursic, J., Viana, M., Wiedensohler, A., and Raes, F.: A European aerosol phenomenology - 3: Physical and chemical characteristics of particulate matter from 60 rural, urban, and kerbside sites across Europe, Atmos. Environ., 44, 1308-1320, 2010.

Quin, Y., Kim, E., and Hopke, P. K.: The concentrations and sources of $\mathrm{PM}_{2.5}$ in metropolitan New York City, Atmos. Environ., 40, 312-332, 2006.

Rahn, K. A. and Lowenthal, D. H.: Pollution aerosol in the Northeast: Northeastern-Midwestern contributions, Science, 19, 275284, 1985.

Rattigan, O. V., Felton, H. D., Bae, M. S., Schwab, J. J., and Demerjian, K. L.: Comparison of long-term $\mathrm{PM}_{2.5}$ carbon measurements at an urban and rural location in New York, Atmos. Environ., 45, 3328-3336, 2011.

Reche, C., Querol, X., Alastuey, A., Viana, M., Pey, J., Moreno, T., Rodríguez, S., González, Y., Fernández-Camacho, R., de la Rosa, J., Dall'Osto, M., Prévôt, A. S. H., Hueglin, C., Harrison, R. M., and Quincey, P.: New considerations for PM, Black Carbon and particle number concentration for air quality monitoring across different European cities, Atmos. Chem. Phys., 11, 6207-6227, doi:10.5194/acp-11-6207-2011, 2011.

Royer, P., Chazette, P., Sartelet, K., Zhang, Q. J., Beekmann, M., and Raut, J.-C.: Comparison of lidar-derived $\mathrm{PM}_{10}$ with regional modeling and ground-based observations in the frame of MEGAPOLI experiment, Atmos. Chem. Phys., 11, 1070510726, doi:10.5194/acp-11-10705-2011, 2011.

Sahu, L. K., Kondo, Y., Miyazaki, Y., Pongkiatkul, P., and Kim Oanh, N. T.: Seasonal and diurnal variations of black carbon and organic carbon aerosols in Bangkok, J. Geophys. Res., 116, D15302, doi:10.1029/2010JD015563, 2011.

Sandradewi, J., Prévôt, A. S. H., Szidat, S., Perron, N., Alfarra, M. R., Lanz, V. A., Weingartner, E., and Baltensperger, U.: Using aerosol light absorption measurements for the quantitative determination of wood burning and traffic emission contributions to particulate matter, Environ. Sci. Technol., 42, 3316-3323, 2008.

Sartelet, K., Debry, E., Fahey, K., Roustan, Y., Tombette, M., and Sportisse, B.: Simulation of aerosols and gas-phase species over Europe with the Polyphemus system. Part I: model-to-data comparison for 2001, Atmos. Environ., 41, 6116-6131, 2007.

Sciare, J.: CNRS press communiqué, available at: http://www2. cnrs.fr/presse/communique/3481.htm?\&theme $1=6 \&$ debut $=16$ (last access: July 2015), 2014.

Seinfeld, J. H. and Pandis, S. N.: Atmospheric Chemistry and Physics - From Air Pollution to Climate Change, 2nd Edition, John Wiley \& Sons, Hoboken, New Jersey, 2006. 
Skyllakou, K., Murphy, B. N., Megaritis, A. G., Fountoukis, C., and Pandis, S. N.: Contributions of local and regional sources to fine PM in the megacity of Paris, Atmos. Chem. Phys., 14, 23432352, doi:10.5194/acp-14-2343-2014, 2014.

Slowik, J. G., Vlasenko, A., McGuire, M., Evans, G. J., and Abbatt, J. P. D.: Simultaneous factor analysis of organic particle and gas mass spectra: AMS and PTR-MS measurements at an urban site, Atmos. Chem. Phys., 10, 1969-1988, doi:10.5194/acp-10-19692010, 2010.

Sun, Y.-L., Zhang, Q., Schwab, J. J., Demerjian, K. L., Chen, W.N., Bae, M.-S., Hung, H.-M., Hogrefe, O., Frank, B., Rattigan, O. V., and Lin, Y.-C.: Characterization of the sources and processes of organic and inorganic aerosols in New York city with a high-resolution time-of-flight aerosol mass apectrometer, Atmos. Chem. Phys., 11, 1581-1602, doi:10.5194/acp-11-15812011, 2011.

Synal, H. A., Stocker, M., and Suter, M.: MICADAS: A new compact radiocarbon AMS system, in: Nuclear Instruments and Methods in Physics Research Section B: Beam Interactions with Materials and Atoms, 259, 7-13, 2007.

Szidat, S., Jenk, T. M., Gäggler, H. W., Synal, H. A., Hajdas, I., Bonani, G., and Saurer, M.: THEODORE, a two-step heating system for the EC/OC determination of radiocarbon (14C) in the environment, in: Nuclear Instruments and Methods in Physics Research Section B: Beam Interactions with Materials and Atoms, 223-224, 829-836, 2004.

Theodosi, C., Im, U., Bougatioti, A., Zarmpas, P., Yenigun, O., and Mihalopoulos, N.: Aerosol chemical composition over Istanbul, Sci. Tot. Environ., 408, 2482-2491, 2010.

Timmermans, R. M. A., Denier van der Gon, H. A. C., Kuenen, J. J. P., Segers, A. J., Honoré, C., Perrussel, O., Builtjes, P. J. H., and Schaap, M.: Quantification of the urban air pollution increment and its dependency on the use of down-scaled and bottom-up city emission inventories, Urban Climate, 6, 46-62, 2013.

Ulbrich, I. M., Canagaratna, M. R., Zhang, Q., Worsnop, D. R., and Jimenez, J. L.: Interpretation of organic components from Positive Matrix Factorization of aerosol mass spectrometric data, Atmos. Chem. Phys., 9, 2891-2918, doi:10.5194/acp-9-2891-2009, 2009.

United Nations: World Urbanization Prospects, the 2015 Revision, available at: esa.un.org/unpd/wup/index.htm (last access: July 2015), 2015.

Veefkind, J. P., De Leeuw, G. D., and Durkee, P. A., Retrieval of aerosol optical depth over land using two-angle view satellite radiometry during TARFOX, Geophys. Res. Lett., 25, 3135-3138, 1998.

Vestreng, V., Mareckova, K., Kakareka, S., Malchykhina, A., and Kukharchyk, T.: Inventory Review 2007; Emission Data reported to LRTAP Convention and NEC Directive, MSC-W Technical Report 1/2007, The Norwegian Meteorological Institute, Oslo, Norway, 2007.

Viana, M., Kuhlbusch, T. A. J., Querol, X., Alastuey, A., Harrison, R. M., Hopke, P. K., Winiwarter, W., Vallius, M., Szidat, S., Prévôt, A. S. H., Hueglin, C., Bloemen, H., Wahlin, P., Vecchi, R., Miranda, A. I., Kasper-Giebl, A., Maenhaut, W., and Hitzenberger, R.: Source apportionment of particulate matter in Europe: a review of methods and results, J. Aerosol Sci., 39, 827-849, 2008 .
Volkamer, R., Jimenez, J. L., Martini, F. S., Dzepina, K., Zhang, Q., Salcedo, D., Molina, L. T., Worsnop, D. R., and Molina, M. J.:, Secondary organic aerosol formation from anthropogenic air pollution: Rapid and higher than expected, Geophys. Res. Lett., 33, L17811, doi:10.1029/2006GL026899, 2006.

von der Weiden-Reinmüller, S.-L., Drewnick, F., Crippa, M., Prévôt, A. S. H., Meleux, F., Baltensperger, U., Beekmann, M., and Borrmann, S.: Application of mobile aerosol and trace gas measurements for the investigation of megacity air pollution emissions: the Paris metropolitan area, Atmos. Meas. Tech., 7, 279-299, doi:10.5194/amt-7-279-2014, 2014a.

von der Weiden-Reinmüller, S.-L., Drewnick, F., Zhang, Q. J., Freutel, F., Beekmann, M., and Borrmann, S.: Megacity emission plume characteristics in summer and winter investigated by mobile aerosol and trace gas measurements: the Paris metropolitan area, Atmos. Chem. Phys., 14, 12931-12950, doi:10.5194/acp14-12931-2014, 2014b.

Yang, F., Tan, J., Zhao, Q., Du, Z., He, K., Ma, Y., Duan, F., Chen, G., and Zhao, Q.: Characteristics of $\mathrm{PM}_{2.5}$ speciation in representative megacities and across China, Atmos. Chem. Phys., 11, 5207-5219, doi:10.5194/acp-11-5207-2011, 2011.

Ye, B. M., Ji, X., Yang, H., Yao, X., Chan, C. K., Cadle, S. H., Chan, T., and Mulawa, P. A.: Concentration and chemical composition of $\mathrm{PM}_{2.5}$ in Shanghai for a 1-year period, Atmos. Environ., 37, 499-510, 2003.

Zhang, Q., Jimenez, J. L., Canagaratna, M. R., Allan, J. D., Coe, H., Ulbrich, I., Alfarra, M. R., Takami, A., Middlebrook, A. M., Sun, Y. L., Dzepina, K., Dunlea, E., Docherty, K., DeCarlo, P. F., Salcedo, D., Onasch, T., Jayne, J. T., Miyoshi, T., Shimono, A., Hatakeyama, S., Takegawa, N., Kondo, Y., Schneider, J., Drewnick, F., Borrmann, S., Weimer, S., Demerjian, K., Williams, P., Bower, K., Bahreini, R., Cottrell, L., Griffin, R. J., Rautiainen, J., Sun, J. Y., Zhang, Y. M., and Worsnop, D. R: Ubiquity and dominance of oxygenated species in organic aerosols in anthropogenically-influenced northern hemisphere mid-latitudes, Geophys. Res. Lett., 34, L13801, doi:10.1029/2007GL029979, 2007.

Zhang, Q., Jimenez, J. L., Canagatna, M. R., Ulbrich, I. M., Ng, N. L., Worsnop, D. R., and Sun, Y.: Understanding atmospheric organic aerosols via factor analysis of aerosol mass spectrometry: a review, Analyt. Bioanalyt. Chem., 401, 3045-3067, 2011.

Zhang, Q. J., Beekmann, M., Drewnick, F., Freutel, F., Schneider, J., Crippa, M., Prevot, A. S. H., Baltensperger, U., Poulain, L., Wiedensohler, A., Sciare, J., Gros, V., Borbon, A., Colomb, A., Michoud, V., Doussin, J.-F., Denier van der Gon, H. A. C., Haeffelin, M., Dupont, J.-C., Siour, G., Petetin, H., Bessagnet, B., Pandis, S. N., Hodzic, A., Sanchez, O., Honoré, C., and Perrussel, O.: Formation of organic aerosol in the Paris region during the MEGAPOLI summer campaign: evaluation of the volatilitybasis-set approach within the CHIMERE model, Atmos. Chem. Phys., 13, 5767-5790, doi:10.5194/acp-13-5767-2013, 2013.

Zotter, P., El-Haddad, I., Zhang, Y., Hayes, P. L., Zhang, X., Lin, Y.-H., Wacker, L., Schnelle-Kreis, J., Abbaszade, G., Zimmermann, R., Surratt, J. D., Weber, R., Jimenez, J. L., Szidat, S., Baltensperger, U., and Prévôt, A. S. H.: Diurnal cycle of fossil and non-fossil carbon using radiocarbon analyses during CalNex, J. Geophys. Res.-Atmos., 119, 6818-6835, doi:10.1002/2013JD021114, 2014. 